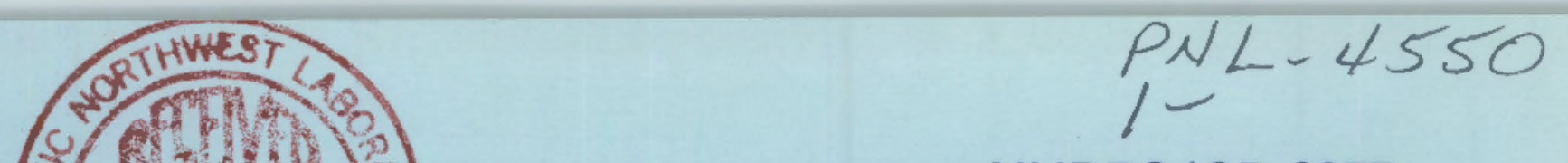

NUREG/CR-2955 PNL-4550

\title{
Analysis of Uranium Urinalysis and In Vivo Measurement Results from Eleven Participating Uranium Mills
}

Prepared by H. B. Spitz, J. C. Simpson, T. L. Aldridge

Pacific Northwest Laboratory

Operated by

Battelle Memorial Institute

Prepared for

U.S. Nuclear Regulatory

Commission 


\section{NOTICE}

This report was prepared as an account of work sponsored by an agency of the United States Government. Neither the United States Government nor any agency thereof, or any of their employees, makes any warranty, expressed or implied, or assumes any legal liability of responsibility for any third party's use, or the results of such use, of any information, apparatus, product or process disclosed in this report, or represents that its use by such third party would not infringe privately owned rights.

\section{NOTICE}

\section{Availability of Reference Materials Cited in NRC Publications}

Most documents cited in NAC publications will be available from one of the following sources:

1. The NRC Public Document Room, 1717 H Street, N.W. Washington, DC 20555

2. The NRC/GPO Sales Program, U.S. Nuclear Regulatory Commission, Washington, DC 20555

3. The National Technical Information Service, Springfield, VA 22161

Although the listing that follows represents the majority of documents cited in NRC publications, it is not intended to be exhaustive.

Referenced documents available for inspection and copying for a fee from the NRC Public Document Room include NRC correspondence and internal NRC memoranda; NHC Office of Inspection and Enforcement bulletins, circulars, information notices, inspection and investigation notices; Licensee Event Reports; vendor reports and correspondence; Commission papers; and applicant and licensee documents and correspondence.

The following documents in the NUREG series are available for purchase from the NRC/GPO Sales Program: formal NRC staff and contractor reports, NRC-sponsored conference proceedings, and NRC booklets and brochures. Also available are Regulatory Guides, NRC regulations in the Code of Federal Regulations, and Nuclear Regulatory Commission Issuances.

Documents available from the National Technical Information Service include NUREG series reports and technical reports prepared by other federal agencies and reports prepared by the Atomic Energy Commission, forerunner agency to the Nuclear Regulatory Commission.

Documents available from public and special technical libraries include all open literature items, such as books, journal and periodical articles, and transactions. Federal Register notices, federal and state legislation, and congressional reports can usually be obtained from these libraries.

Documents such as theses, dissertations, foreign reports and translations, and non-NRC conference proceedings are available for purchase from the organization sponsoring the publication cited.

Single copies of NRC draft reports are available free, to the extent of supply, upon written request to the Division of Technical Information and Document Control, U.S. Nuclear Regulatory Com. mission, Washington, DC 20555.

Copies of industry codes and standards used in a substantive manner in the NRC regulatory process are maintained at the NRC Library, 7920 Norfolk Avenue, Bethesda, Maryland, and are available there for reference use by the public. Codes and standards are usually copyrighted and may be purchased from the originating organization or, if they are American National Standards, from the American National Standards Institute, 1430 Broadway, New York, NY 10018. 
NUREG/CR-2955

PNL-4550

\section{Analysis of Uranium Urinalysis and In Vivo Measurement Results from Eleven Participating Uranium Mills}

Manuscript Completed: March 1984

Date Published: May 1984

Prepared by

H. B. Spitz, J. C. Simpson, T. L. Aldridge

Pacific Northwest Laboratory

Richland, WA 99352

Prepared for

Division of Radiation Programs and Earth Sciences

Office of Nuclear Regulatory Research

U.S. Nuclear Regulatory Commission

Washington, D.C. 20555

NRC FIN B2283 


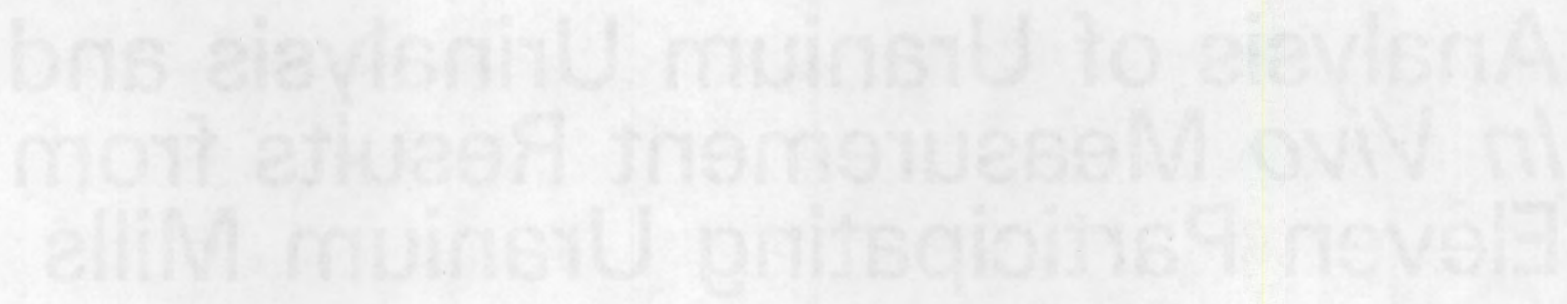




\section{ABSTRACT}

Uranium urinalysis and in vivo examination results obtained from workers at eleven uranium mills between 1978 and 1980 were evaluated by Pacific Northwest Laboratory (PNL) at the request of the U.S. Nuclear Regulatory Commission (NRC). The main purpose of this evaluation was to determine the degree of the mills' compliance with bioassay monitoring recommendations given in the draft NRC Regulatory Guide 8.22 (USNRC 1978). The effect of anticipated changes in the draft regulatory guidance, as expressed to PNL in May 1982, was also studied.

Statistical analyses of the data showed that the bioassay results did not reliably meet the limited performance criteria given in the draft regulatory guide. Furthermore, quality control measurements of uranium in urine indicated that detection limits at $\alpha=\beta=0.05$ ranged from $13 \mu \mathrm{g} / \ell$ to $29 \mu \mathrm{g} / \mathrm{l}$, whereas the draft regulatory guidance suggests $5 \mu \mathrm{g} / \mathrm{l}$ as the detection limit. Recommendations for monitoring frequencies given in the draft guide were not followed consistently from mill to mill.

The results of these statistical analyses indicate a need to include performance criteria for accuracy, precision, and confidence in revisions of the draft Regulatory Guide 8.22. Revised guidance should also emphasize the need for each mill to continually test the laboratory performing urinalyses by submitting quality control samples (i.e., blank and spiked urine samples as open and blind tests) to insure that the performance criteria are being met. Recommendations for a bioassay audit program are also given. 



\section{CONTENTS}

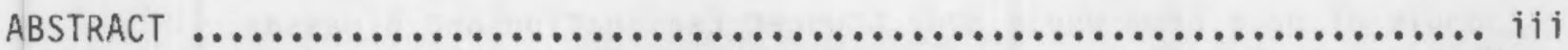

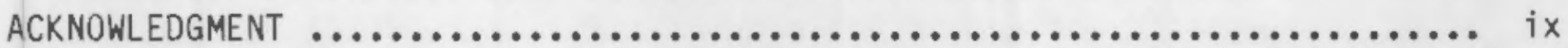

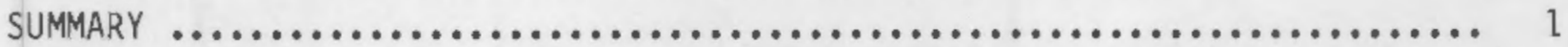

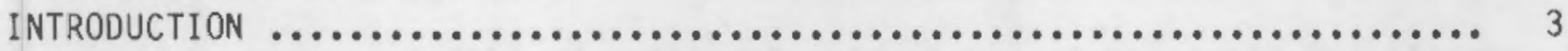

METHODS

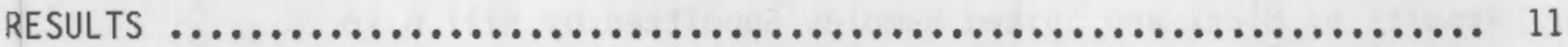

LIMITS OF DETECTION $\ldots \ldots \ldots \ldots \ldots \ldots \ldots \ldots \ldots \ldots \ldots \ldots \ldots \ldots \ldots \ldots, 11$

RELATIVE FREQUENCY DISTRIBUTIONS OF URANIUM URINALYSES $\ldots \ldots \ldots \ldots \ldots, 14$

RELATIVE FREQUENCY DISTRIBUTIONS OF IN VIVO EXAMINATIONS $\ldots \ldots \ldots \ldots . .18$

RFLATIONSHIPS BETWEEN URANIUM URINALYSES AND IN VIVO

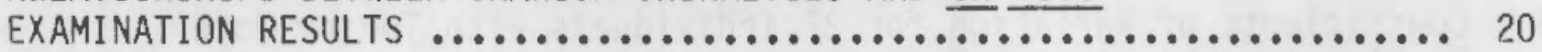

CORRELATION OF URANIUM URINALYSES, IN VIVO, AND

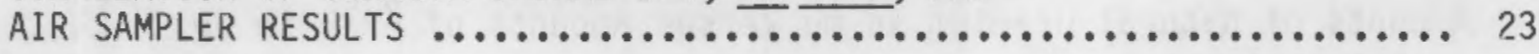

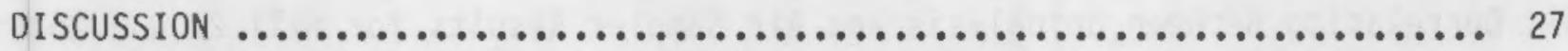

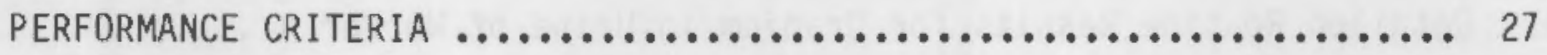

URINALYSIS RESULTS $\ldots \ldots \ldots \ldots \ldots \ldots \ldots \ldots \ldots \ldots \ldots \ldots \ldots \ldots \ldots \ldots, 28$

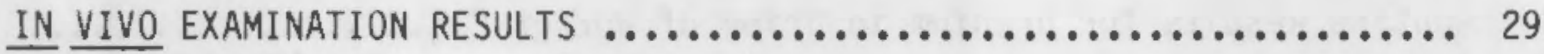

CONCLUSIONS

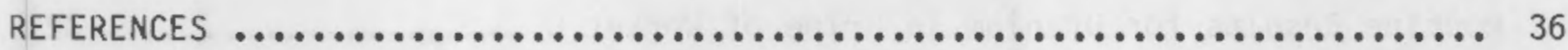

APPENDIX A - EXAMPLES OF RAW DATA SUBMITTED BY THE URANIUM MILLS ........ A.1 APPENDIX B - RECOMMENDATIONS FOR BIOASSAY PERFORMANCE CRITERIA AND AN AUDIT PROGRAM TO TEST THE LABORATORY $\ldots \ldots \ldots \ldots \ldots \ldots . . .1$ 


\section{FIGURES}

1 Sample of Data From Whole Body Counter Examination and Bioassay Measurement Results ........................................ 7

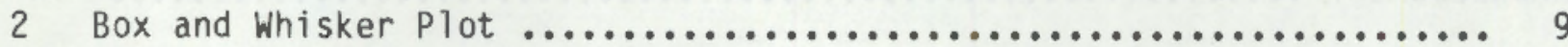

$3 L_{c}$ and $L_{d}$ for (a) $\alpha=\beta=0.05$ and (b) $\alpha=\beta=0.10 \ldots \ldots \ldots \ldots \ldots .10$

4 Results of Blank and Spiked Samples Submitted by Mill 6 to Laboratory $\mathrm{A}$.......................................... 12

5 Results of Blank and Spiked Samples Submitted by Mill 6 to Laboratory B .......................................... 12

6 Results of Blank and Spiked Samples Submitted by Mill 2 to Laboratory $C$............................................. 13

7 Results of Spiked Samples Prepared and Analyzed by Laboratory C for Mill 9 ................................................ 13

8 Coefficients of Variation for 27 Individuals with Two or More

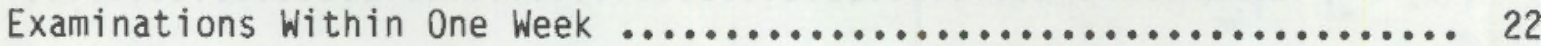

9 Amounts of Natural Uranium in mg Versus Amounts of $235 \mathrm{U}$ in $\mu \mathrm{g} . \ldots . . .24$

10 Correlation Between Urinalysis and Air Sampler Results for Mill 2.... 25

11 Detailed Routine Results for Uranium in Urine of Worker A ......... 30

12 Detailed Routine Results for Uranium in Urine of Worker B ......... 30

13 Routine Results for Uranium in Urine of Worker $C \ldots \ldots \ldots \ldots \ldots . . . .31$

14 Routine Results for Uranium in Urine of Worker A $\ldots \ldots \ldots \ldots \ldots \ldots \ldots, 31$

15 Routine Results for Uranium in Urine of Worker D $\ldots \ldots \ldots \ldots \ldots \ldots \ldots, 32$ 


\section{TABLES}

1 Record Format Used for Analysis of Uranium in Urine $\ldots . \ldots \ldots \ldots \ldots . .5$

2 Record Format Used for Whole Body Counter Examinations ............ 6

3 Estinated $L_{c}, L_{d}$ Values for Laboratories $A, B$, and $C \ldots \ldots \ldots \ldots . .14$

4 Coefficients of Variation for $30 \mu \mathrm{g}$ of $U / \ell \ldots \ldots \ldots \ldots \ldots \ldots \ldots . .14$

5 Number of Workers and Uranium Urinalyses per Mill $\ldots \ldots \ldots \ldots \ldots \ldots, 15$

6 Relative Frequency Distribution of Uranium Urinalysis Results $\ldots \ldots \ldots 16$

7 Frequency of Uranium Urinalyses Results $\geq 15$ and $\geq 30 \mu \mathrm{g}$ of $\mathrm{U} / \ell \ldots \ldots . .17$

8 Number of Workers with One or More Uranium Urinalysis Result

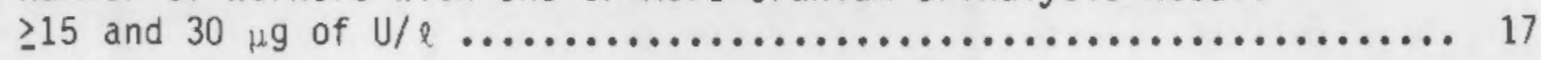

9 Mean Percentage of Total Uranium Urinalysis Results $\geq 15 \mu \mathrm{g}$ of $\mathrm{U} / \mathrm{l}$

for workers with One or More Results $\geq 15 \mu \mathrm{g}$ of $\mathrm{U} / \ell \ldots \ldots \ldots \ldots \ldots \ldots . .18$

10 Mean Percentage of Total Uranium Urinalysis Results $\geq 30 \mu \mathrm{g}$ of $\mathrm{V} / \mathrm{l}$.

for Workers with One or More Results $\geq 30 \mu \mathrm{g}$ of $\mathrm{U} / 2 \ldots \ldots \ldots \ldots \ldots . .18$

11 Number of Workers and In Vivo Examinations Per Mill

12 Number of Whole Body Counter Examinations $\geq 8$ and $14 \mathrm{mg}$ of Uranium ... 20

13 Relative Frequency of In Vivo Examination Results $\ldots \ldots \ldots \ldots \ldots \ldots \ldots .21$

14 Uranium Analysis and In Vivo Examination Results $\ldots \ldots \ldots \ldots \ldots \ldots \ldots 22$

15 Relationship Between Natural Uranium and $235 \mathrm{U}$ Measured In Vivo ..... 23

15 Correlation of In Vivo Examinations with Urinalysis and Air Sampler

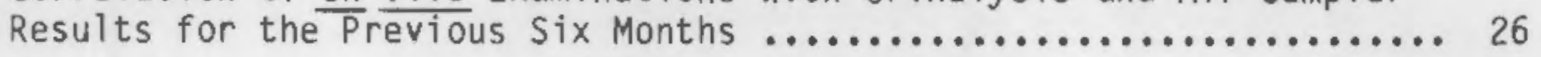

B.1 Bioassay Data for Natural Uranium Blank Audit Samples $\ldots . \ldots \ldots \ldots \ldots$. B.3 



\section{ACKNOWLEDGMENT}

The authors wish to thank Jan Lewis and John Bower who provided the major programming assistance during the development of this data base system. Dave Hickman and Bob Robinson provided invaluable technical advice. Special acknowledgment is given to Nancy Dennis who provided us with the data and guided us through the final presentation. The authors also thank Sharon Popp for typing the initial drafts of the statistical data tables. Special thanks are directed to Mary Ann McKinney and Ron-Kathren for editing and reviewing the many drafts of this report. The authors also thank Dr. Allen Brodsky for his suggestions and guidance. Darrell Fisher served as project manayer. 



\section{ANALYSIS OF URANIUM URINALYSIS AND IN VIVO MEASUREMENT RESULTS FROM ELEVEN PARTICIPATING URANIUM MILLS}

\section{SUMMARY}

Bioassay data collected between 1978 and 1980 by eleven uranium mills were evaluated by PNL at the request of the NRC. The primary objectives of the study were to evaluate the quality of the data and to determine whether bioassay monitoring practices at these eleven mills were consistent with recommendations given in the draft NRC Regulatory Guide 8.22 (USNRC 1978).

The only performance criteria for bioassay measurements cited in the draft NRC regulatory guidance are minimum detection limits for uranium urinalyses and in vivo examinations. The data in this study did not meet these criteria at the $95 \%$ confidence level; however, this level is not required in the draft regulatory guidance. Overall, these bioassay results were found to be highly variable and, thus, unreliable as a monitoring tool to determine whether millworkers have been exposed to airborne uranium. Measurement reliability would be improved significantly if guidance were proffered to establish minimum acceptable limits for measurement accuracy (bias), precision, and confidence. Furthermore, laboratories or vendors that perform uranium urinalyses or in vivo examinations must be tested on a routine basis by mill personnel to insure that the performance criteria are, in fact, being met.

The degree with which bioassay monitoring programs were found to comply with the draft NRC regulatory guidance varied from mill to mill and was apparently unrelated to the size of the work force or the type of yellowcake produced at the mill. Recordkeeping practices at the mills, as exemplified by the bioassay data received for study, were inadequate, at best. Records were essentially incomplete and could not easily be reviewed or analyzed for trends.

Both the regulatory agency and the uranium milling industry would benefit from an explicit statement of guidelines for performance criteria, recordkeeping, and testing their bioassay laboratories or vendors. With such guidelines, the reliability of bioassay measurement programs will be improved from that observed in this study. 



\section{INTRODUCTION}

Yellowcake is the generic term applied to the end product of uranium milling. It has many different chemical forms and varies markedly from mill to mill, or even within the same batch produced at a single mill because of differences in uranium extraction and drying processes. Despite its name, yellowcake is not necessarily yellow but may be dark green or black when dried at high temperatures. The drying mechanism may produce yellowcake that is a fine powder or granular in appearance.

The drying temperature of uranium supposedly predicts the behavior of the yellowcake in the human respiratory system because it may affect the solubility of yellowcake in the lung and its ultimate translocation from the lung to other body organs and tissues (Eidson 1980; Kalkwarf 1979). For example, oxides created by high-temperature drying are, in general, the least soluble in lung fluid and hence produce the greatest radiological hazard to the lungs. Soluble yellowcake materials are less hazardous to the lungs but present a greater radiological and toxicological risk to other internal body organs and tissue (i.e., skeleton and kidney). Eidson and Mewhinney (1980), in their study of yellowcake dissolution conducted in vitro using simulated lung fluid, find that yellowcake solubility in vivo may be highly variable because the chemical composition of yellowcake varies greatly.

Routine urinalysis and in vivo examinations for uranium are proposed in the draft NRC Regulatory Guide 8.22 (USNRC 1978) as monitoring procedures for selected uranium mill workers. The terms "whole body count" and "in vivo examination" are used interchangeably in this report to represent a quantitative measurement of uranium present in the respiratory system of a worker by use of photon detectors placed on the anterior thorax. Results are used to verify that control procedures, which are designed to limit airborne uranium exposure to workers at the mill, are adequate. Furthermore, these monitoring procedures can also confirm the intake of uranium in an exposed worker and be used to evaluate dose resulting from internally deposited uranium. Whenever uranium bioassay measurements indicate that a uranium uptake may have occurred, actions can be taken by the mill health physicist to protect affected workers from any further uptake.

The objective of this work was to analyze uranium urinalysis and in vivo examination results from workers at eleven participating uranium mills from 1978 through 1980 and determine how well these bioassay monitoring programs complied with recommendations given in the draft NRC Regulatory Guide 8.22 USNRC 1978). We also were requested to study what impact, if any, might be expected from proposed changes in the draft regulatory guidance for bioassay at uranium mills. Management personnel from these eleven uranium mills volunteered the bioassay data to the NRC, which then requested that PNL perform the following tasks:

- determine the number and frequency of individual uranium urinalysis and whole body counter (WBC) examination results that exceed recommended and proposed (May 1982) action levels 
- determine the number and frequency of individuals whose uranium urinalysis or WBC examination results exceed recommended and proposed (May 1982) action levels

- describe the distribution of uranium urinalysis and WBC examination results for each mill and for all the mills in the group

- evaluate the quality of the data obtained from the mills and investigate any observed trends

- investigate relationships or correlations among uranium urinalysis, $W B C$, and air sampler results

- recommend a uranium urinalysis sampling frequency based upon the observed excretion (or retention) of uranium in mill workers.

The NRC further requested an evaluation of the bioassay data to determine the degree to which uranium mills were meeting the recommendations specified in the draft regulatory guidance. Measurement results were compared to the investigation level $(15 \mu \mathrm{g} / \mathrm{l})$, action level $(30 \mu \mathrm{g} / \mathrm{l})$, and the detection level $(5 \mu \mathrm{g} / l)$ specified in the draft regulatory guide. In addition, the data were also evaluated against NRC's proposed action and investigation levels for uranium in urine as considered in May 1982 (viz., 20 and $32 \mu \mathrm{g} / \ell$ ).

The NRC has proposed monitoring guidelines for bioassay measurements to aid in assessing the uranium exposure hazards of the work place. Uranium mill health physicists are expected to respond appropriately whenever bioassay measurement results approach or exceed levels considered potentially hazardous. Therefore, bioassay measurements should be highly reliable at those levels so that the frequency of false negative bioassay results is acceptably low for unknowingly exposed workers. This concept of measurement reliability is not part of the draft regulatory guidance, but we considered it important enough to include in the evaluation of the uranium mill bioassay data. 


\section{METHODS}

This study involved 17,039 urinalysis and 1,677 in vivo uranium measurement results obtained from 1,369 and 909 workers, respectively. A PDP $11 / 70$ minicomputer was used to process and store this data using a commercially available database management software package called "TOTAL". A computer file, containing uranium bioassay data as well as other related information, was created for each mill worker. Tables 1 and 2 illustrate the format used for uranium urinalysis and in vivo measurement results, respectively. A reproduction of a page from a worker's computer file is illustrated in Figure 1.

TABLE 1. Record Format Used for Analysis of Uranium in Urine (BI0)

Item

Name

ID

Job

Date
Specifications

First initials plus full last name, if available. This field is nonessential since ID \# will be the fixed identifier.

Nine alphanumeric characters for Social Security number or other unique identifier created from a composite of mill and worker ID number. A unique worker number may be assigned if no other identification is provided by the mill.

The title or work location of the mill worker.

Date of collection (mo/d/yr) may be incomplete since some data exclude day.

DL Flag Detection level flag -- used whenever the result is equal to or less than the detection level for the particular procedure used by the mill or laboratory. The database will not contain the actual detection level value but will only flag those results that are appropriate.

Result The result is always assumed to be natural uranium and reported in $\mu \mathrm{g} / \ell$.

Error Reported measurement error, if any.

Mill ID A unique identifier code will be assigned to each mill.

Refer

Whenever any other result (WBC, BIO, or AIR) is relatable to this result, a code is entered.

Comment Thirty-character alphanumeric field. $\pm 123.4$

$\frac{\text { Example }}{A B \text { Watanable }}$

$999-99-9999$

Acid Leach

072078

123.4

99

$W, B, A$ 
TABLE 2. Record Format Used for Whole Body Counter Examinations (WBC)

\begin{tabular}{|c|c|c|}
\hline Item & Specifications & _Example \\
\hline Name & $\begin{array}{l}\text { First initials plus full last name, if available. } \\
\text { This field is nonessential since ID \# will be the } \\
\text { fixed identifier. }\end{array}$ & $A B$ Watanable \\
\hline ID & $\begin{array}{l}\text { Nine alphanumeric characters for Social Security num- } \\
\text { ber or other unique identifier created from a compo- } \\
\text { site of mill and worker ID number. A unique worker } \\
\text { number may be assigned if no other identification is } \\
\text { provided by the mill. }\end{array}$ & $999-99-9999$ \\
\hline Job & The titie or work location of the mill worker. & Crusher \\
\hline Date & $\begin{array}{l}\text { Date of collection (mo/d/yr) may be incomplete since } \\
\text { some data exclude day. }\end{array}$ & 071278 \\
\hline Time & Time of the examination (24-h clock). & 1730 \\
\hline Result & Natural uranium. & 123.4 \\
\hline Error & Reported measurement error, if any. & \pm 123.4 \\
\hline Units & $\begin{array}{l}\text { Natural uranium may be reported in nCi or mg. Only } \\
\text { results in mg will be stored. Results reported in } \\
\text { nCi will be converted to mg upon entry. A conversion } \\
\text { equation will be created for this purpose. }\end{array}$ & $\mathrm{mg}$ \\
\hline Result & $235 \mathrm{U}$ & 123 \\
\hline Error & Reported measurement error, if any. & \pm 123 \\
\hline Units & Micrograms. & $\mu \mathrm{g}$ \\
\hline Result & Some measurement results are available for $226 \mathrm{Ra}$. & 12 \\
\hline Error & Reported measurement error, if any. & \pm 99 \\
\hline Units & Nanocurie. & $\mathrm{nCi}$ \\
\hline Mill ID & $\begin{array}{l}\text { A unique identification code will be assigned to } \\
\text { each mill. }\end{array}$ & 99 \\
\hline Refer & $\begin{array}{l}\text { Whenever any other result (WBC, BIO, or AIR) is } \\
\text { relatable to this result, a code is entered. }\end{array}$ & $W, B, A$ \\
\hline Comment & Thirty-character alphanumeric field. & \\
\hline
\end{tabular}




\section{ID}

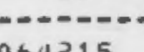

064215

BIO MEASUREIAENT

n. B. EXamitiation

$$
\text { NAME }
$$

JUH UR LOCATION

MILL SS NO

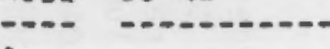

0

ENKITR DET FL ALI COMYENT 1

AT HOME

A T HOME

AT HOME

AI HOME

AT NORK
REF

(i.)

1). 1)

u. U

0.0

0.0

6.0

0.0

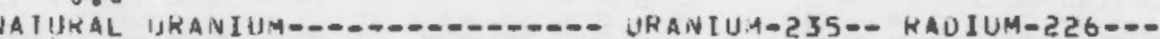

\begin{tabular}{|c|c|c|c|c|c|c|c|c|c|c|c|c|}
\hline MO DAY YE & I I ME & MG & EKRUR & NSC I & ERROR & ALI & MICRO & ERROR & NCI & ERROR & REF & COMMENT \\
\hline$-2-0-10-2$ & $\cdots-$ & $-----\infty$ &.---0 & $-0-2-0$ &.----- & -- & $\cdots$ & $--2--0$ & $-\infty-\pi-$ & $-\infty-\infty-0$ & $-\infty$ & $-0--0-0-0$ \\
\hline $07-21-74$ & $11: 50$ & 0.0 & 0.0 & 2.5 & 1.6 & & 0.0 & 47.0 & 0.0 & 0.0 & & \\
\hline $119-25-18$ & $08: 00$ & 0.0 & 0.0 & 1.4 & 1.2 & & 0.0 & 44.0 & 0.0 & 0.0 & & \\
\hline$n 6-14-18$ & U9: 35 & 0.0 & 2.0 & 0.0 & 0.0 & & 0.0 & 41.0 & 0.0 & 0.0 & & \\
\hline $117-20=77$ & $19: 18$ & 0.0 & 2.0 & 0.0 & 0.0 & & 0.0 & 0.0 & 0.0 & 0.0 & & \\
\hline
\end{tabular}

FIGURE 1. Sample of Data From Whole Body Counter Examination and Bioassay Measurement Results 
Various mathematical expressions and terminology can be used to describe detection limits. Knowledge of detection limits and their reliability is critical if unknowingly exposed workers are identified solely from the results of routine bioassay monitoring. The statistical expressions adopted for this study (Currie 1978) involve establishing a decision limit, a detection limit, and a determination limit.

The decision limit $\left(L_{c}\right)$ is the point at which the measurement procedure indicates the presence of the substance of interest (in this case uranium). The value of $L_{c}$ was calculated so that an incorrect decision (i.e., uranium was present when actually it was absent) was made only $\alpha \times 100 \%$ of the time, where the value of $\alpha$ was adopted a priori according to the degree of confidence needed to avoid false positive results. If the measured value was less than $\mathrm{L}_{c}$, uranium was assumed to be absent; if the measurement result was greater than $L_{C}$, the sample was considered likely to contain uranium. The quantity of $L_{c}$ was determined solely from measuring urine samples known to contain no uranium other than that amount derived naturally from a person's diet (i.e., blanks).

The detection limit $\left(L_{d}\right)$ is based upon a specified degree of confidence in rejecting false negative results. It is the point at which $\beta \times 100 \%$ of the results for samples containing $L_{d}$ uranium are below the $L_{c}$ and, thus, are judged to contain no uranium when, in fact, uranium is present. The value of $p$ was adopted a priori according to the degree of confidence needed to avoid false negative resuTts. Therefore, the $L_{d}$ is the smallest quantity of uranium that could be detected in a sample with the probability 1 - $R$ when $L_{C}$ is the decision limit.

The determination limit $\left(L_{q}\right)$ is defined as the point at which the analytical procedure is sufficiently precise to yield a satisfactory quantitative result. At the $L_{q}$ the relative standard deviation is sufficiently small that the procedure yields a result close to the mean value. At the $L_{d}$, however, analytical procedure is only precise enough to yield a qualitative estimate (presence or absence) of uranium. When the $\mathrm{L}_{g}$ is reached (which may be several times larger than $L_{d}$ ), the results of the procedure will be more useful in a quantitative sense, such as for dose evaluation.

Appendix $B$ indicates how, for Gaussian distributed results, the quantities $L_{c}$ and $L_{d}$ were calculated when a large number of blank and spiked samples were analyzed. Gaussian techniques were not used for this study because the laboratories performing the uranium urinalyses reported results for all measurements below their announced detection limit as "less than detection." This type of reporting, which statisticians call "data censoring", means that valid measurement results were discarded regardless of whether they were negative or highly unreliable. Therefore, to overcome data censoring, a pictorial, nonparametric technique was adopted to calculate $L_{c}$ and $L_{d}$.

Figure 2 illustrates the "Box and Whisker" (BW) plot adopted as a nonparametric technique for this study. The rectangular box and its two "whiskers" were used in place of the Gaussian curve to illustrate how measurement results were distributed. The median of the distribution is shown by a vertical line 


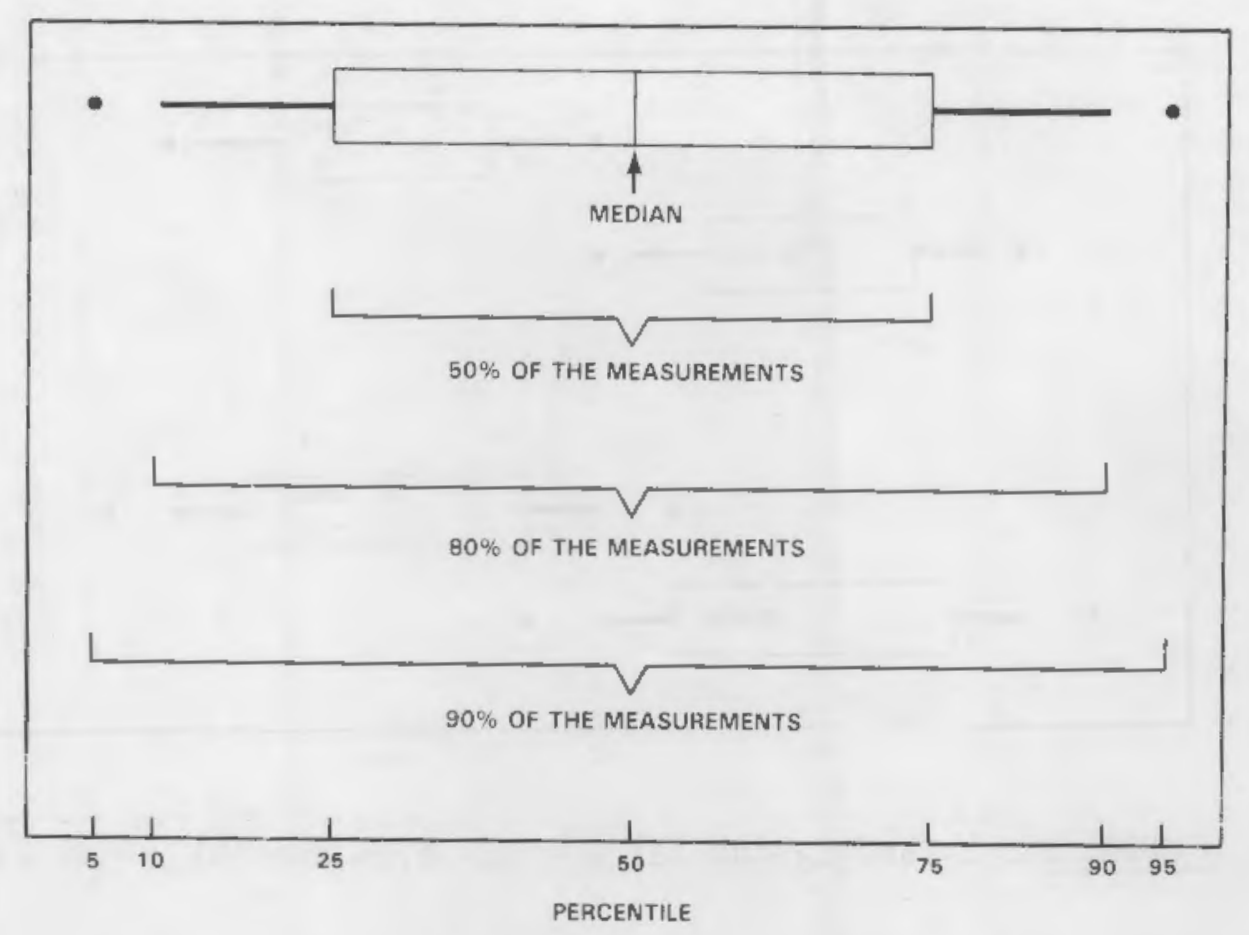

FIGURE 2. Box and Whisker P1ot

orawn within the box at the appropriate place above the abscissa. The box is arawn such that its length includes $50 \%$ of the results along the abscissa. The length of the rectangular box plus its two whiskers represent $80 \%$ of the measured results. Ninety percent of the measurement results are distributed between the two dots drawn outside the whiskers of the rectangular box. If the data are censored, one end of the symmetric BW plot can be eliminated. Thus, the $5 \mathrm{th}, 10 \mathrm{th}, 25 \mathrm{th}$, 50th (median), 75th, 90th, and 95th percentiles of the data set can be illustrated in a pictorial manner.

The values of $L_{c}$ and $L_{d}$ are determined by graphically comparing the $B W$ plots showing the distribution of blank and spiked sample results as illustrated in Figure 3. If the values of $L_{C}$ and $L_{d}$ are defined such that $\alpha=\beta=$ 0.05 , then the BW plots should have the spatial relationship shown in the top half of Figure 3 where the 95th percentile (dot at the end of whisker) of the blank sample distribution should coincide (overlap) with the fifth percentile of the spiked samples. If $L_{c}$ and $L_{d}$ are defined such that $\alpha=\beta=0.10$, then the BW plots will be spatialiy related as shown in the bottom half of Figure 3 where the 90th percentile (end of the whisker) of the blank samples distribution should coincide (overlap) with the 10th percentile of the spiked sample distribution. In these examples, the median of the blank sample distributions equals zero.

The majority of the remaining limited objectives were completed using the computer to generate relative frequency distributions of various related data elements. These frequency distributions disclosed numbers and percentages of 


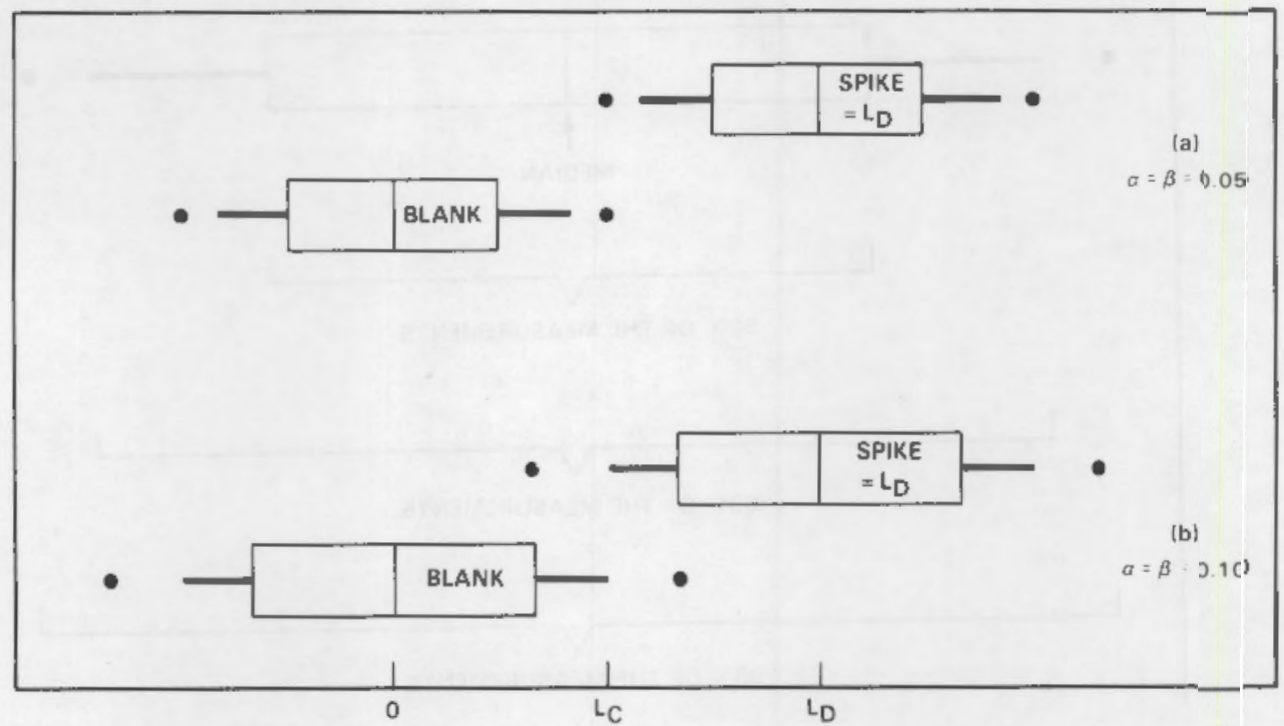

FIGURE 3. $L_{C}$ and $L_{d}$ for (a) $\alpha=\beta=0.05$ and (b) $\alpha=\beta=0.10$

uranium urinalyses and in vivo examinations performed for each worker at each mill and whether the results exceeded NRC recommended and proposed levels for action. 
RESULTS

The draft NRC Regulatory Guide 8.22 (USNRC 1978) advises uranium mill health physicists to routinely check laboratories performing the mill's urinalyses by submitting samples containing known amounts of uranium along with blanks. Furthermore, the draft regulatory guidance specifies that test samples should be adjusted to contain $15 \mu \mathrm{g}$ of $\mathrm{U} / \ell$ or $30 \mu \mathrm{g}$ of $\mathrm{U} / \ell$ because these are the action or investigation levels specified by the NRC in the draft regulatory guidance. Blanks, of course, have no added uranium other than that excreted naturally from uranium in the diet.

\section{LIMITS OF DETECTION}

Only two mills (Mill 2 and Mill 6) submitted adequate test sample results from which $L_{c}$ and $L_{d}$ could be calculated. Mill 6 submitted test samples unknown (blind) to Laboratories $A$ and $B$, whereas Mill 2 openly identified test samples submitted to Laboratory C. Unlike Mills 2 and 6 , Mill 9 did not submit test samples to Laboratory $C$. Instead, Laboratory $C$ was required to report results of their own spiked samples to Mill 9. Laboratory $C$ did not report blank sample results for Mill 9 , so $L_{c}$ and $L_{d}$ could not be calculated. The distribution of test sample results is illustrated with BW plots in Figures 4 through 7 .

The distribution of results from test samples reported by Laboratory $C$ for Mill 9 (Figure 7) was anomalous relative to the other distributions and was probably due to an inherent bias associated with Laboratory $C$ processing its own test samples. Mill 2 also uses Laboratory $C$ but the results were distributed as expected (Figure 6 ). Mill 2 test results appeared similar to those obtained by Mill 6 which uses Laboratory A (Figure 4) and Laboratory B

(Figure 5 ). These results indicated that the mills should submit blind test samples to evaluate true laboratory performance.

According to the BW plots (Figures 4 through 6 ), the way in which the 95 th percentile of the blank results approached the 5 th percentile of the spiked sample distributions indicated that Laboratories $A, B$, and $C$ would not achieve an $L_{d}$ equal to $5 \mu \mathrm{g}$ of $\mathrm{U} / \ell$. Five outliers having values greater than $29 \mu \mathrm{g}$ of $\mathrm{U} /$ \& were observed among results reported by Laboratory $\mathrm{C}$ on blanks submitted by Mil1 2. These were eliminated from the data set before estimating $L_{C}$. These results were so much higher than the remaining results (whose highest value was $16 \mathrm{\mu g}$ of $\mathrm{U} / \mathrm{l}$ ) that the deleted blanks were assumed to have been contaminated. The actual values of $L_{c}$ and $L_{d}$ were estimated by interpolation and are shown in Table 3 for $\alpha=\beta=0.05$ and for $\alpha=\beta=0.10$. Thus, even when $\alpha$ and $\beta$ errors are relaxed and set at $10 \%$, only Laboratory $B$ could achieve a detection limit as good as $10 \mu \mathrm{g}$ of $\mathrm{U} / \ell$. However, Laboratory $B$ would still fail to comply with the draft NRC regulatory guidance which specifies $L_{d}=5 \mu g$ of $\mathrm{U} / 2$.

The BW plots also illustrate that results for test samples containing $30 \mu$ of $\mathrm{U} / \ell$ were highly variable. The coefficients of variation (CV) for the $30 \mu \mathrm{g}$ of $\mathrm{U} / \ell$ test samples are shown in Table 4. 


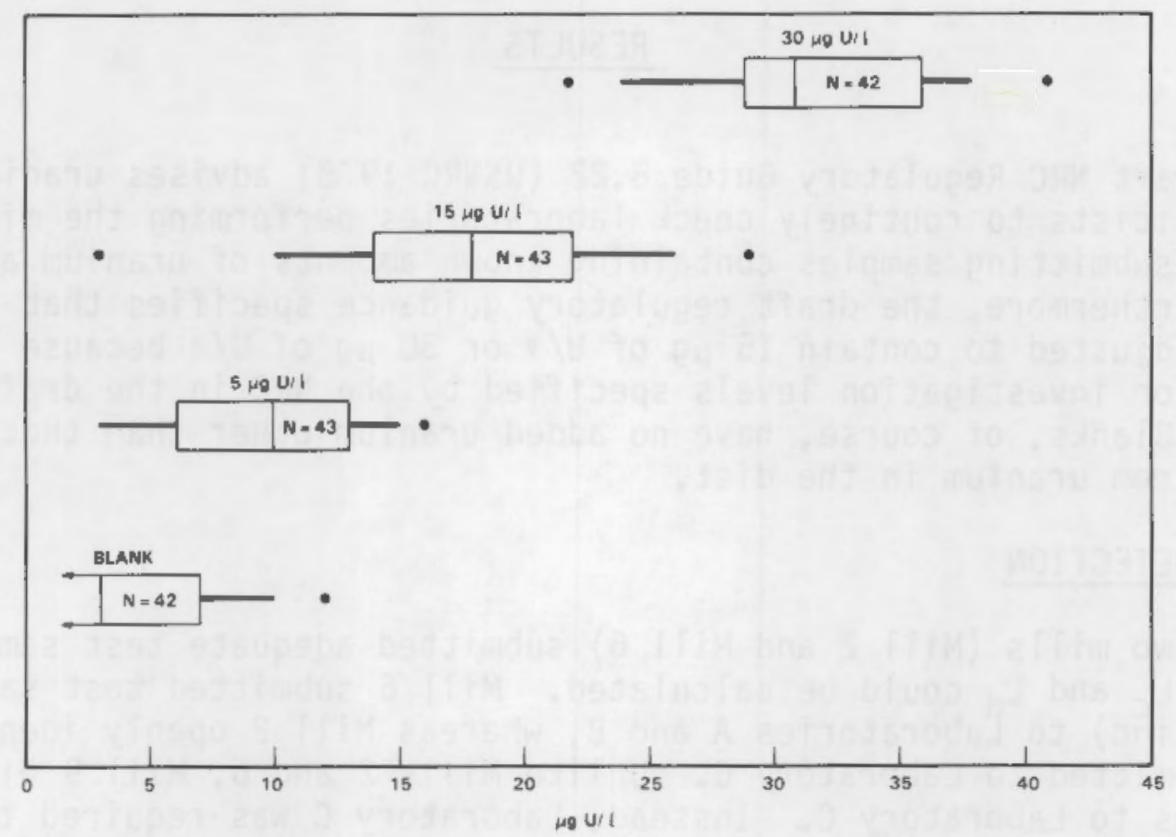

FIGURE 4. Results of Biank and Spiked Samples Subinitted by Mill 6 to Laboratory $A$

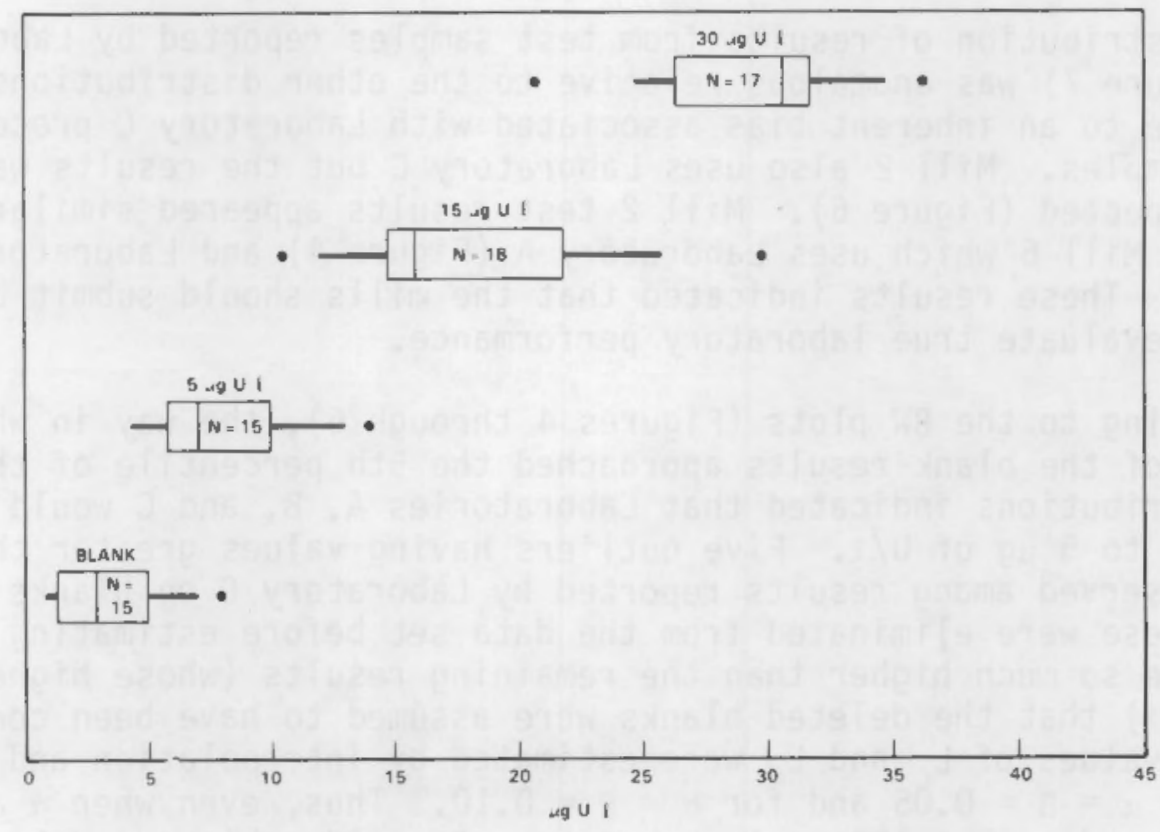

FIGURE 5. Results of Blank and Spiked Samples Submitted by Mil1 6 to Laboratory B 


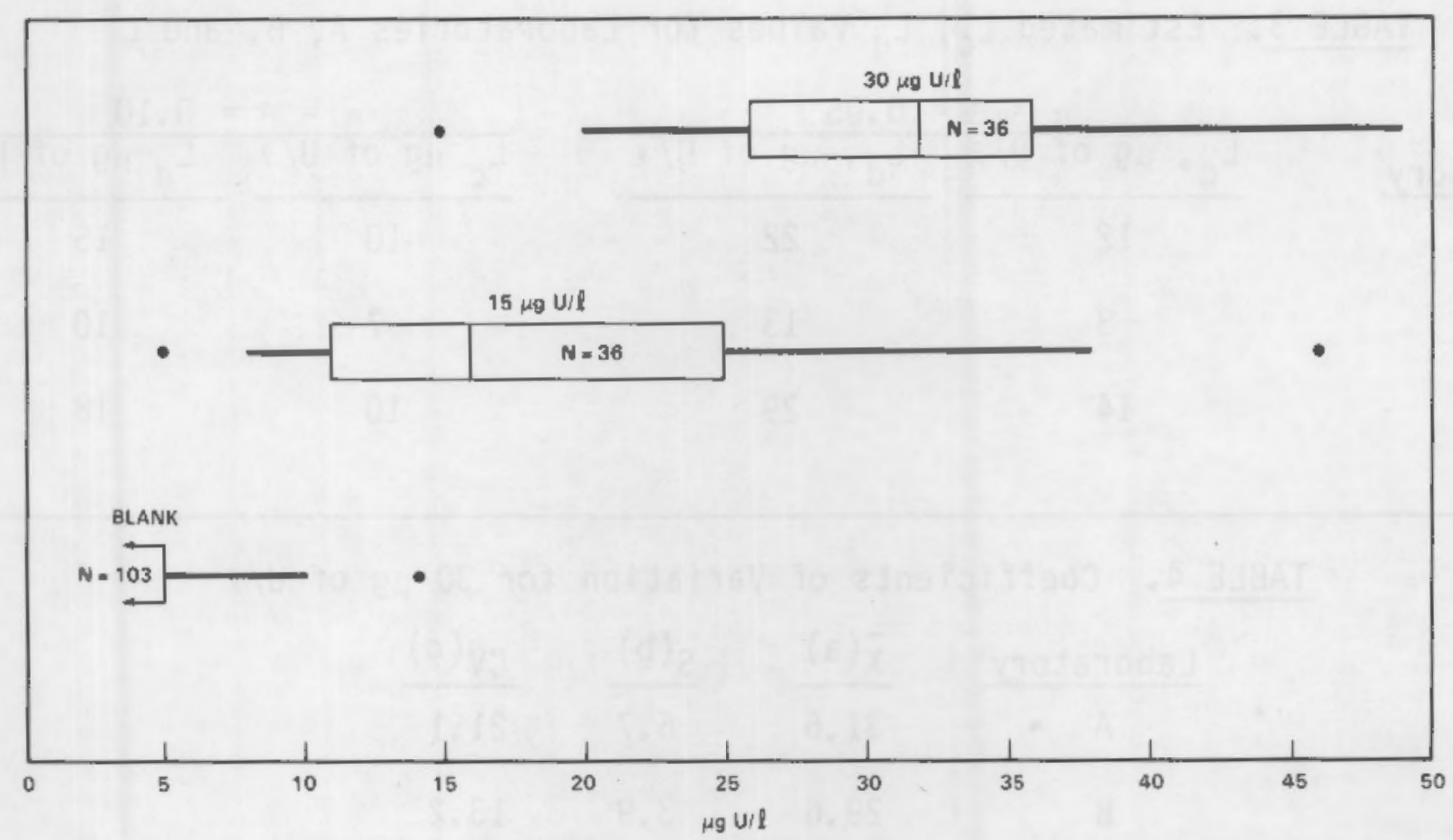

FIGURE 6. Results of Blank and Spiked Samples Submitted by Mill 2 to Laboratory C

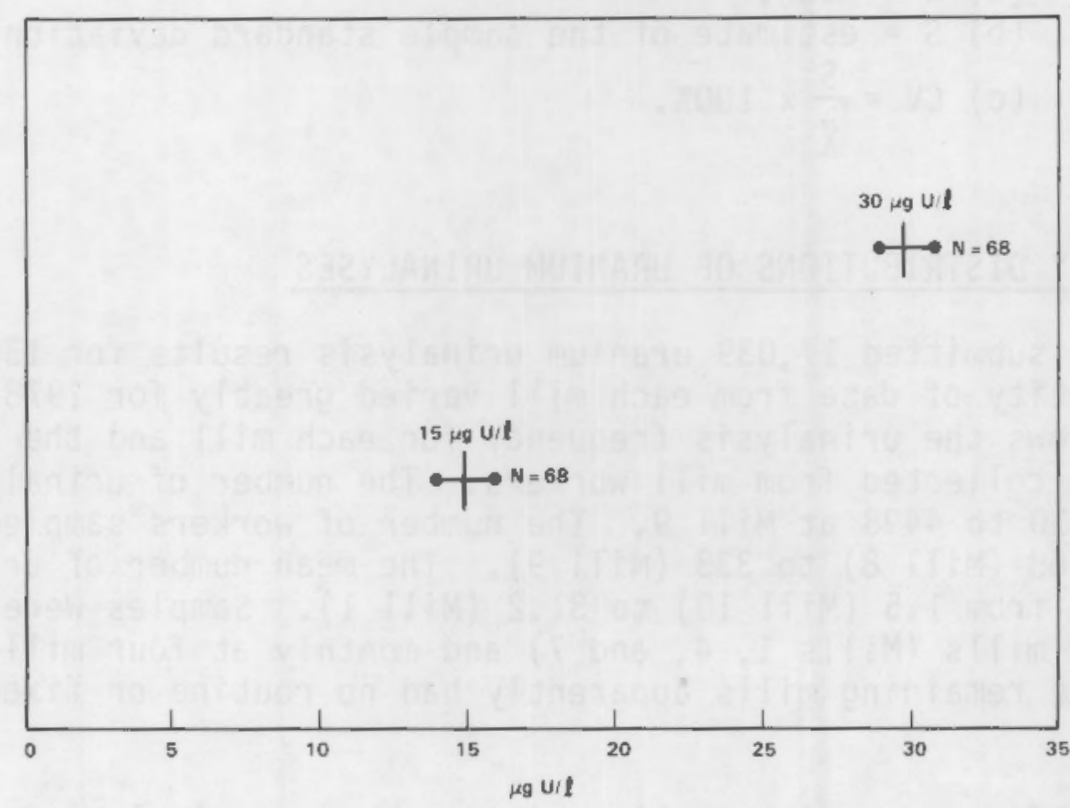

FIGURE 7. Results of Spiked Samples Prepared and Analyzed by Laboratory C for Mill 9 
TABLE 3. Estimated $L_{c}, L_{d}$ Values for Laboratories $A, B$, and $C$

\begin{tabular}{|c|c|c|c|c|}
\hline \multirow[b]{2}{*}{ Laborato } & \multicolumn{2}{|c|}{$x=\beta=0.05$} & \multicolumn{2}{|c|}{$\alpha=\beta=0.10$} \\
\hline & $L_{C}, \mu g$ of $U / \ell$ & $\mathrm{L}_{\mathrm{d}}, \mu \mathrm{g}$ of $\mathrm{U} / \mathrm{l}$ & $L_{c} \mu g$ of $U / 9$ & $L_{d} \mu g$ of $U / l$ \\
\hline A & 12 & 22 & 10 & 15 \\
\hline B & 8 & 13 & 7 & 10 \\
\hline $\mathrm{C}$ & 14 & 29 & 10 & 18 \\
\hline
\end{tabular}

TABLE 4. Coefficients of Variation for $30 \mu \mathrm{g}$ of $\mathrm{U} / \mathrm{\ell}$

$\begin{array}{crrr}\frac{\overline{\text { Laboratory }}}{\text { A }} & \frac{\bar{X}(\mathrm{a})}{31.6} & \frac{\mathrm{S}(\mathrm{b})}{6.7} & \frac{\mathrm{CV}(\mathrm{c})}{21.1} \\ \text { B } & 29.6 & 3.9 & 13.2 \\ \text { C } & 34.8 & 11.9 & 34.1\end{array}$
(a) $\bar{x}=$ mean.
(b) $\mathrm{S}=$ estimate of the sample standard deviation.
(c) $\mathrm{CV}=\frac{\mathrm{S}}{\overline{\mathrm{X}}} \times 100 \%$.

RELATIVE FREQUENCY DISTRIBUTIONS OF URANIUM URINALYSES

Eleven mills submitted 17,039 uranium urinalysis results for 1369 workers; however, the quantity of data from each mill varied greatly for 1978 through 1980. Table 5 shows the urinalysis frequency for each mill and the average number of samples collected from mill workers. The number of urinalyses ranged from 122 at Mill 10 to 4498 at Mill 9. The number of workers sampled at each mill ranged from 68 (Mill 8) to 333 (Mill 9). The mean number of urinalyses per worker ranged from 1.5 (Mill 10) to 31.2 (Mill 1). Samples were collected biweekly at three inills (Mills 1, 4, and 7) and monthly at four mills (Mills 2, $6,8$, and 9$)$. The remaining mills apparently had no routine or fixed sampling schedule.

The relative frequency distribution of the uranium urinalysis results for each mill is given in Table 6 . Results for all mills appeared to be lognormally distributed.

Table 7 shows the distribution of uranium urinalysis results at each mill relative to the action levels specified in the draft NRC regulatory guidance (viz., $15 \mu \mathrm{g}$ of $\mathrm{U} / \mathrm{l}$ and $30 \mu \mathrm{g}$ of $\mathrm{U} / \mathrm{l}$ ). Overall, $12.4 \%$ of the results would equal or exceed $15 \mu \mathrm{g}$ of $\mathrm{U} / \mathrm{l}$, and $3.2 \%$ would equal or exceed $30 \mu \mathrm{g}$ of $\mathrm{U} / \mathrm{l}$. 
TABLE 5. Number of Workers and Uranium Urinalyses per Mill (1978 to 1980)

\begin{tabular}{|c|c|c|c|c|}
\hline Mill & $\begin{array}{l}\text { Number of } \\
\text { Workers }\end{array}$ & $\begin{array}{l}\text { Number of } \\
\text { Urinalyses }\end{array}$ & $\begin{array}{l}\text { Urinalyses } \\
\text { Per Worker }\end{array}$ & $\begin{array}{l}\text { Sampling } \\
\text { Frequency }\end{array}$ \\
\hline 1 & 83 & 2587 & 31.2 & Biweekly \\
\hline 2 & 91 & 1129 & 12.1 & Monthiy \\
\hline 3 & 138 & 255 & 1.8 & $\ldots-(a)$ \\
\hline 4 & 147 & 2343 & 15.9 & Biweek $1 y$ \\
\hline 5 & 126 & 568 & 4.5 &.$--(a)$ \\
\hline 6 & 72 & 2169 & 30.1 & Month1y \\
\hline 7 & 129 & 2385 & 18.5 & Biweekly \\
\hline 8 & 68 & 560 & 8.2 & Monthly \\
\hline 9 & 333 & 4498 & 13.5 & Monthly \\
\hline 10 & 81 & 122 & 1.5 & $\ldots(a)$ \\
\hline 11 & $\frac{101}{1369}$ & $\frac{423}{17039}$ & 4.2 & $\ldots(a)$ \\
\hline
\end{tabular}

(a) A routine sampling frequency could not be determined from data. Either these mills did not adopt a routine sampling frequency for urinalyses or mill operations may have been curtailed.

However, considerable variability in the urinalysis result data existed among the mills. For example, at Mills 3 and 8 all results were well below the first action level, whereas Mills 4 and 9 each had approximately $19 \%$ of their results equal or exceeding $15 \mu \mathrm{g}$ of $\mathrm{U} / \mathrm{\ell}$.

The frequency with which a worker's uranium urinalyses exceeded action limits may indicate a need to limit the worker's exposure. If the frequency is high, the process responsible for the exposure condition would need to be redesigned or restructured. Possibly, the workers should use respiratory protection. The data presented in Table 8 show there were 540 workers $(25.5 \%)$ with one or more uranium urinalysis result equal or exceeding $15 \mu \mathrm{g}$ of $\mathrm{U} / \mathrm{l}$ and 265 workers $(12.5 \%$ ) with one or more result equal or exceeding $30 \mathrm{\mu g}$ of $\mathrm{U} / \mathrm{l}$. The results varied widely among individual mills.

The efficacy of uranium exposure controls and health physics monitoring practices at mills can be determined by evaluating the percentage of uranium urinalyses that exceed action levels. For example, mills with effective controls would rarely expect to find a high percentage of workers repeatedly excreting uranium above action limits. Table 9 shows the average percentage of urinalysis results equal to or exceeding $15 \mu \mathrm{g}$ of $\mathrm{U} / \ell$ for workers with one or more results equal to or exceeding this action level. Table 10 shows a similar analysis for uranium urinalyses equal to or exceeding $30 \mu \mathrm{g}$ of $\mathrm{U} / \mathrm{l}$. Only 
TABLE 6. Relative Frequency Distribution of Uranium Urinalysis Results

Uranium

Concentration, $\mu \mathrm{g}$ of $\mathrm{U} / \mathrm{l}$

\begin{tabular}{|c|c|c|c|c|c|c|c|c|c|c|c|}
\hline 1 & 2 & 3 & 4 & 5 & 6 & 7 & 8 & 9 & 10 & 11 & Total \\
\hline 2012 & 512 & 219 & 998 & 403 & 1331 & 1427 & 369 & 2101 & 91 & 295 & 9758 \\
\hline 479 & 264 & 35 & 502 & 101 & 374 & 337 & 156 & 892 & 12 & 86 & 3238 \\
\hline 95 & 189 & 1 & 397 & 35 & 231 & 270 & 35 & 637 & 7 & 28 & 1925 \\
\hline 1 & 62 & 0 & 174 & 17 & 81 & 144 & 0 & 328 & 4 & 5 & 816 \\
\hline 0 & 38 & 0 & 100 & 4 & 55 & 75 & 0 & 207 & 3 & 4 & 486 \\
\hline 0 & 16 & 0 & 54 & 4 & 27 & 44 & 0 & 125 & 1 & 2 & 273 \\
\hline 0 & 14 & 0 & 41 & 2 & 17 & 32 & 0 & 54 & 0 & 1 & 161 \\
\hline 0 & 7 & 0 & 22 & 0 & 7 & 13 & 0 & 39 & 2 & 2 & 92 \\
\hline 0 & 11 & 0 & 21 & 1 & 11 & 18 & 0 & 46 & 2 & 0 & 110 \\
\hline 0 & 10 & 0 & 14 & 1 & 12 & 18 & 0 & 33 & 0 & 0 & 88 \\
\hline 0 & 2 & 0 & 8 & 0 & 4 & 2 & 0 & 13 & 0 & 0 & 29 \\
\hline 0 & 4 & 0 & 10 & 0 & 8 & 5 & 0 & 14 & 0 & 0 & 41 \\
\hline 0 & 0 & 0 & 1 & 0 & 4 & 0 & 0 & 4 & 0 & 0 & 9 \\
\hline 0 & 0 & 0 & 1 & 0 & 5 & 0 & 0 & 3 & 0 & 0 & 9 \\
\hline 0 & 0 & 0 & 0 & 0 & 2 & 0 & 0 & 2 & 0 & 0 & 4 \\
\hline 2587 & 1129 & 255 & 2343 & 568 & 2169 & 2385 & 560 & 4498 & 122 & 423 & 17039 \\
\hline
\end{tabular}


TABLE 7. Frequency of Uranium Urinalyses Results $\geq 15$ and $\geq 30 \mu \mathrm{g}$ of $\mathrm{U} / \ell$

\begin{tabular}{|c|c|c|c|c|c|}
\hline \multirow[b]{2}{*}{ Mill } & \multirow{2}{*}{$\begin{array}{l}\text { Number of } \\
\text { Urinalyses }\end{array}$} & \multicolumn{2}{|c|}{ Results $\geq 15 \mu \mathrm{g}$ of $\mathrm{U} / \mathrm{\ell}$} & \multicolumn{2}{|c|}{ Results $\geq 30 \mu \mathrm{g}$ of $\mathrm{U} / \mathrm{l}$} \\
\hline & & Number & Percent & Number & Percent \\
\hline 1 & 2587 & 1 & $<0.1$ & 0 & 0.0 \\
\hline 2 & 1129 & 164 & 14.5 & 48 & 4.3 \\
\hline 3 & 255 & 0 & 0.0 & 0 & 0.0 \\
\hline 4 & 2343 & 446 & 19.0 & 118 & 5.0 \\
\hline 5 & 568 & 29 & 5.1 & 4 & 0.7 \\
\hline 6 & 2169 & 233 & 10.7 & 70 & 3.2 \\
\hline 7 & 2385 & 351 & 14.7 & 88 & 3.7 \\
\hline 8 & 560 & 0 & 0.0 & 0 & 0.0 \\
\hline 9 & 4498 & 868 & 19.3 & 208 & 4.6 \\
\hline 10 & 122 & 12 & 9.8 & 4 & 3.3 \\
\hline 11 & 423 & 14 & 3.3 & 3 & 0.7 \\
\hline Totals & 17039 & 2118 & 12.4 & 543 & 3.2 \\
\hline
\end{tabular}

TABLE 8. Number of Workers with One or More Uranium Urinalysis Result $\geq 15$ and $30 \mu \mathrm{g}$ of $\mathrm{U} / \mathrm{e}$.

\begin{tabular}{|c|c|c|c|c|c|}
\hline \multirow[b]{2}{*}{ Mill } & \multirow{2}{*}{$\begin{array}{c}\text { Number of } \\
\text { Workers }\end{array}$} & \multicolumn{2}{|c|}{$\begin{array}{l}\text { Workers with one or More } \\
\text { Results } \geq 15 \mu \mathrm{g} \text { of } \mathrm{U} / \ell\end{array}$} & \multicolumn{2}{|c|}{$\begin{array}{l}\text { Workers with One or More } \\
\text { Results } \geq 30 \mu \mathrm{H} \text { of } \mathrm{U} / \ell\end{array}$} \\
\hline & & Number & Percent & Number & Percent \\
\hline 1 & 83 & 1 & 1.2 & 0 & 0.0 \\
\hline 2 & 91 & 62 & 68.1 & 30 & 33.0 \\
\hline 3 & 138 & 0 & 0.0 & 0 & 0.0 \\
\hline 4 & 147 & 116 & 78.9 & 59 & 40.1 \\
\hline 5 & 126 & 27 & 21.4 & 4 & 3.2 \\
\hline 6 & 72 & 57 & 79.2 & 40 & 55.6 \\
\hline 7 & 129 & 80 & 62.0 & 39 & 30.2 \\
\hline 8 & 68 & 0 & 0.0 & 0 & 0.0 \\
\hline 9 & 333 & 178 & 53.5 & 86 & 25.8 \\
\hline 10 & 81 & 8 & 9.9 & 4 & 4.9 \\
\hline 11 & 101 & 11 & 10.9 & 3 & 3.0 \\
\hline Totals & 1369 & 540 & 25.5 & 265 & 12.5 \\
\hline
\end{tabular}


TABLE 9. Mean Percentage of Total Uranium Urinalysis Results $\geq 15 \mu \mathrm{g}$ of $\mathrm{U} / \ell$ for Workers with One or More Results $\geq 15 \mu \mathrm{g}$ of $\mathrm{U} / \ell$

\begin{tabular}{|c|c|c|c|}
\hline Mill & $\begin{array}{l}\text { Workers with } \\
\text { One or More Results } \\
\geq 15 \mu \mathrm{g} \text { of } \mathrm{U} / \ell\end{array}$ & $\begin{array}{l}\text { Number of Results } \\
\geq 15 \mu \text { of } \mathrm{U} / \mathrm{e}\end{array}$ & $\begin{array}{l}\text { Average Percent } \\
\text { of Total Results } \\
\geq 15 \mu \mathrm{g} \text { of } \mathrm{U} / \mathrm{\Omega}\end{array}$ \\
\hline 2 & 62 & 164 & 24.3 \\
\hline 4 & 116 & 446 & 32.1 \\
\hline 6 & 57 & 233 & 12.1 \\
\hline 7 & 80 & 351 & 20.0 \\
\hline 9 & 178 & 868 & 28.1 \\
\hline
\end{tabular}

TABLE 10. Mean Percentage of Total Uranium Urinalysis Results $\geq 30 \mu \mathrm{g}$ of $\mathrm{U} / \ell$ for Workers with One or More Results $\geq 30 \mu \mathrm{g}$ of $\mathrm{U} / \ell$

\begin{tabular}{|c|c|c|c|}
\hline Mill & $\begin{array}{l}\text { Workers with } \\
\text { One or More Results } \\
\geq 30 \mu \mathrm{g} \text { of } \mathrm{U} / \mathrm{\ell} \\
\end{array}$ & $\begin{array}{c}\text { Number of Results } \\
\geq 30 \mu \mathrm{g} \text { of } \mathrm{U} / \mathrm{l} \\
\end{array}$ & $\begin{array}{l}\text { Average Percent } \\
\text { of Total Results } \\
\geq 30 \mu \mathrm{g} \text { of } \mathrm{U} / \mathrm{\ell} \\
\end{array}$ \\
\hline 2 & 30 & 48 & 14.4 \\
\hline 4 & 59 & 118 & 19.0 \\
\hline 6 & 40 & 70 & 5.3 \\
\hline 7 & 39 & 88 & 11.0 \\
\hline 9 & 86 & 208 & 17.9 \\
\hline
\end{tabular}

Mills 2, 4, 6, 7, and 9 were included in these tables because the remaining mills did not have enough data to make the analysis meaningful.

RELATIVE FREQUENCY OISTRIBUTIONS OF IN VIVO EXAMINATIONS

Nine mills submitted 1677 in vivo examination results for 909 workers. Unlike the urinalyses results, differences observed in in vivo results cannot be attributed to vendors because the same whole body counter examination service was used by all mills. Table 11 shows the number and frequency of in vivo examinations for each mill.

The frequency with which in vivo examination results exceeded action limits specified in the draft $\overline{N R C}$ regulatory guidance (viz., $8 \mathrm{mg}$ and $14 \mathrm{mg}$ of uranium) is shown on Table 12. There were 412 in vivo uranium examination results $(24.6 \%)$ that equaled or exceeded $8 \mathrm{mg}$ and 75 results $(4.5 \%)$ that equaled or exceeded $14 \mathrm{mg}$. The data for Mill 5 were divided into two categories because results for 1978 were significantly different from later years. For example, in 1978 Mill 5 had 57 results (93.4\%) that equaled or exceeded $8 \mathrm{mg}$ of uranium and 47 results $(77.1 \%)$ that equaled or exceeded $14 \mathrm{mg}$ of 
TABLE 11. Number of Workers and In Vivo Examinations Per Mill

\begin{tabular}{|c|c|c|c|}
\hline Mill & Number of Workers & Number of Examinations & Examinations Per Worker \\
\hline 1 & 95 & 119 & . $\quad 1.3$ \\
\hline 2 & 84 & 95 & 1.1 \\
\hline 3 & 49 & 55 & 1.1 \\
\hline 4 & 42 & 73 & 1.7 \\
\hline 5 (a) & 61 & 61 & 1.0 \\
\hline $5^{(b)}$ & 111 & 189 & 1.7 \\
\hline 6 & 158 & 369 & 2.3 \\
\hline 7 & 177 & 355 & 2.0 \\
\hline 8 & 20 & 20 & 1.0 \\
\hline 9 & 172 & 341 & 2.0 \\
\hline Totals & 909 & 1677 & \\
\hline
\end{tabular}

(a) For 1978 only.

(b) For 1979 and 1980.

uranium. Mill 5's results for 1978 were so different from those in 1979 and 1980 (and different from results at all other mills) that the cause of the unusual distribution should be identified or the validity of the results questioned. No information was submitted by mill 5 or the vendor to explain the unusual results for 1978 .

The relative frequency distribution of all in vivo uranium examination results is shown in Table 13. Unlike uranium urinalysis results, in vivo uranium measurement results are apparently not log-normally distributed.

Test data was not available to determine $L_{c}$ and $L_{d}$ for in vivo examinations because neither the vendor nor the mills submitted calibration or background data for the whole body counter. However, we can make use of the fact that 27 individuals received two or more in vivo examinations within one week, calculate the $\mathrm{CV}$ for these sequential exams and infer the quality of the measurements from the magnitude of the observed variations. Repeat measurements of this sort are usually performed to verify an initially high result. Large variations in sequential in vivo examination results may be due to surface contamination on the skin which the worker removes by showering or changing cloths between the exams. An in vivo exam should effectively discriminate against surface contamination because the objective is to measure internally deposited activity, in this case uranium in the lungs rather than uranium on the skin. 
TABLE 12. Number of Whole Body Counter Examinations $\geq 8$ and $14 \mathrm{mg}$ of Uranium

\begin{tabular}{|c|c|c|c|c|c|}
\hline \multirow[b]{2}{*}{ Mill } & \multirow[b]{2}{*}{ No. } & \multicolumn{2}{|c|}{ Examinations $\geq 8 \mathrm{mg}$} & \multicolumn{2}{|c|}{ Examinations $\geq 14 \mathrm{mg}$} \\
\hline & & Number & Percent & Number & Percent \\
\hline 1 & 119 & 12 & 10.1 & 1 & 0.8 \\
\hline 2 & 95 & 10 & 10.5 & 0 & 0.0 \\
\hline 3 & 55 & 1 & 1.8 & 0 & 0.0 \\
\hline 4 & 73 & 11 & 15.1 & 1 & 1.4 \\
\hline $5(a)$ & 61 & 57 & 93.4 & 47 & 77.1 \\
\hline $5^{(b)}$ & 189 & 40 & 21.2 & 3 & 1.6 \\
\hline 6 & 369 & 144 & 39.0 & 11 & 3.0 \\
\hline 7 & 355 & 66 & 18.6 & 6 & 1.7 \\
\hline 8 & 20 & 14 & 70.0 & 1 & 5.0 \\
\hline 9 & $\underline{341}$ & 57 & 16.7 & 5 & 1.5 \\
\hline Totals & 1677 & 412 & 24.6 & 75 & 4.5 \\
\hline $\begin{array}{l}\text { minus } \\
\text { s } 1978\end{array}$ & 1616 & 355 & 22.0 & 28 & 1.7 \\
\hline
\end{tabular}

(a) For 1978 only.

(b) For 1979 and 1980.

A BW plot of the $\mathrm{CV}$ for 27 individuals is shown in Figure 8. Fifty percent of these 27 individuals had CVs greater than $23 \%$. Other sources which inight contribute to this high variability include procedural changes, detector background fluctuations or new acute or chronic uranium exposures since the last in vivo examination. Because the same vendor was used by all mills, the differences between mills could not be attributed to differences between vendors.

\section{RELATIONSHIPS BETWEEN URANIUM URINALYSES AND IN VIVO EXAMINATION RESULTS}

Routine monitoring programs should reliably identify workers who become unknowingly exposed to uranium on the job. Although uranium urinalysis and in vivo examination results may not jointly confirm any particular exposure because of metabolic differences in yellowcake materials, mills with consistently high exposures should rank high in both urinalyses and in vivo results. Therefore, to investigate the relationship between uranium urinalyses and in vivo examination results, the percentage of urinalyses equal to or exceeding $\overline{15 \mu \mathrm{g}}$ of $\mathrm{U} / \ell$ and in vivo examinations equal to or exceeding $8 \mu \mathrm{g}$ of $\mathrm{U} / \mathrm{l}$ were ranked in descending order. The results of this ranking are shown in Table 14. Mill 8, which had no urinalyses results above the action level (i.e., $15 \mu \mathrm{g}$ of $\mathrm{U} / \ell$ ), was ranked highest for the percentage of in vivo examinations equal to or 
TABLE 13. Relative Frequency of In Vivo Examination Results

Examination Mills (Frequency)

Totals Less

Mill 5 's

Results

for $U, \mathrm{mg}$

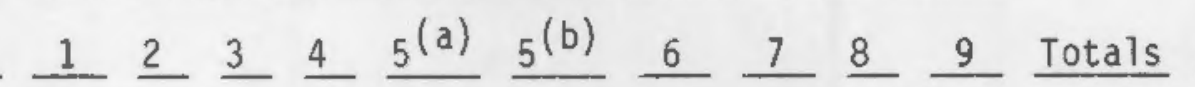

1978 Results

$<1$

$\begin{array}{llll}31 & 2 & 40 & 6\end{array}$

238

238

$1<2$

27

$$
0
$$

$\begin{array}{llll}11 & 19 & 7 & 6\end{array}$

$0 \quad 5$

$\begin{array}{llllll}5 & 1 & 1 & 0 & 6 & 23\end{array}$

23

$2<3$

$\begin{array}{llll}17 & 20 & 2 & 17\end{array}$

27

$\begin{array}{llll}11 & 23 & 0 & 54\end{array}$

159

159

$3<4$

$\begin{array}{llll}15 & 14 & 2 & 9\end{array}$

$0 \quad 38$

$25 \quad 33$

$4<5$

$\begin{array}{llll}17 & 10 & 2 & 9\end{array}$

$0 \quad 33$

$5<6$

$\begin{array}{llll}14 & 13 & 1 & 15\end{array}$

$0 \quad 32$

$31 \quad 45$

$6<8$

$\begin{array}{llll}10 & 7 & 1 & 9\end{array}$

33

$45 \quad 38$

$\begin{array}{lll}1 & 42 & 195\end{array}$

195

$8<10$

$$
\begin{array}{lllll}
0 & 3 & 0 & 1 & 6
\end{array}
$$

14

96

$\begin{array}{llll} & 1 & 32 & 182\end{array}$

182

$10<12$

$12<14$

$\begin{array}{lll}1 & 0 & 0\end{array}$

0

3

5

74

71

$\begin{array}{lll}0 & 48 & 200\end{array}$

200

$14<16$

$16<20$

0

0

1

4

2

541

$\begin{array}{llll}40 & 6 & 32 & 184\end{array}$

290

$20<25$

$\begin{array}{llll}1 & 0 & 0 & 0\end{array}$

9

2.18

$\begin{array}{lll}13 & 3 & 15\end{array}$

87

183

$25<30$

$\begin{array}{llll}0 & 0 & 0 & 0\end{array}$

10

2

25

$\begin{array}{lllll}8 & 7 & 4 & 5 & 40\end{array}$

40

19

18

13

$\begin{array}{llllll}8 & 0 & 1 & 0 & 0 & 0\end{array}$

9

$30<35$

$$
\begin{array}{llll}
0 & 0 & 0 & 0
\end{array}
$$

110

$35<40$

$40<50$

$50<75$

$75<100$

$\geq 100$

Totals

$$
\begin{array}{llll}
0 & 0 & 0 & 0
\end{array}
$$

10

$\begin{array}{llll}0 & 0 & 0 & 0\end{array}$

20

$\begin{array}{llll}0 & 0 & 0 & 0\end{array}$

10

0

0

00

11

1

00

0

1

2

81

37

15

$\begin{array}{llll}0 & 0 & 0 & 0\end{array}$

$$
\begin{aligned}
& \frac{0}{119} \frac{0}{95} \frac{0}{55} \\
& \text { anly. } 1980 .
\end{aligned}
$$

(b) For 1979 and 1980.

exceeding $8 \mathrm{mg}$ of U. In contrast, Mill 3, which also had no urinalyses results above the action level, was ranked lowest for the percentage of in vivo examinations equal or exceeding $8 \mathrm{mg}$ of $U$. These differences in ranks are inconsistent with the expectations of a uranium mill's routine personnel monitoring program especially because both mills were producing yellowcake of the same generic solubility (i.e., dried at high temperatures). 


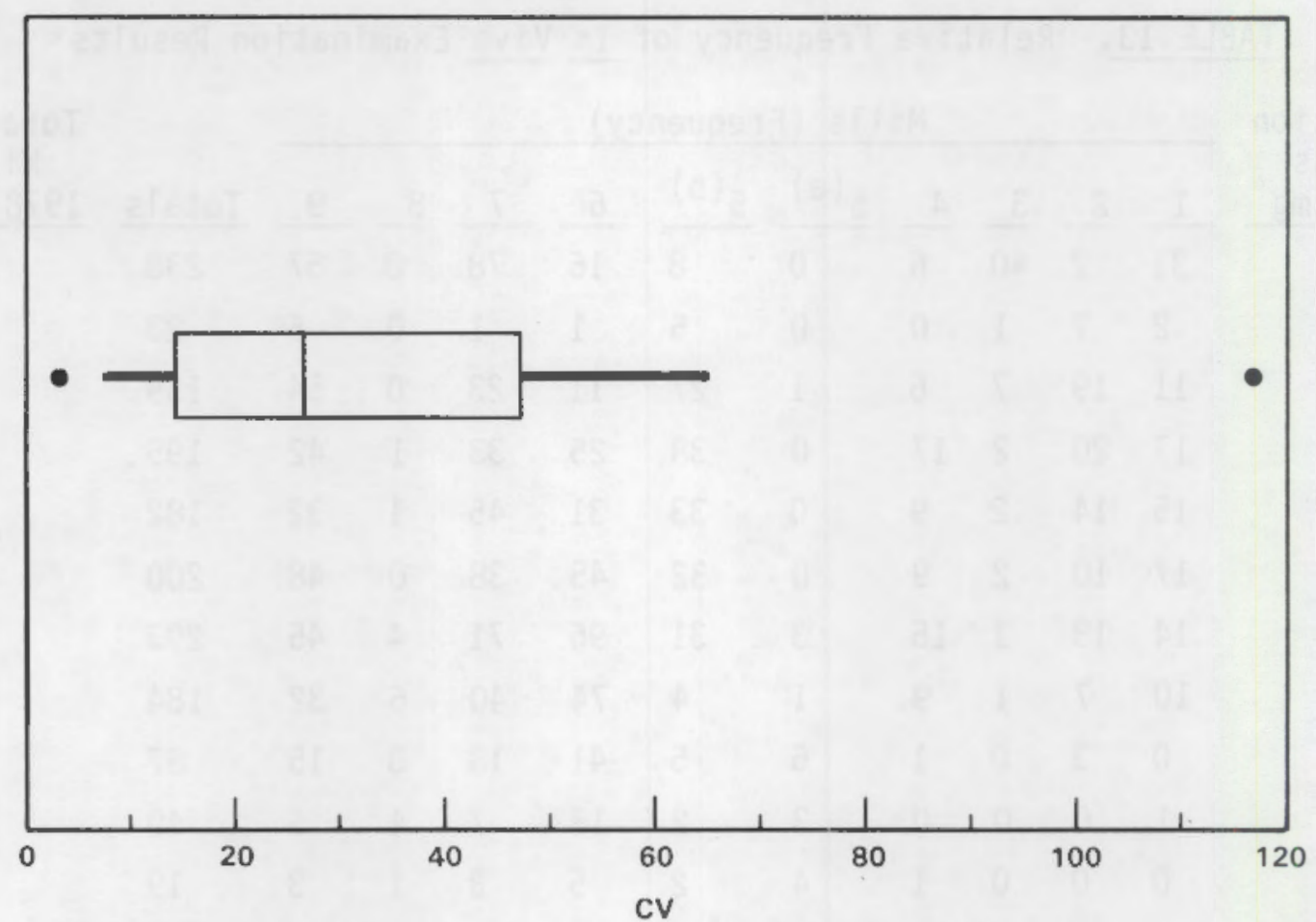

FIGURE 8. Coefficients of Variation for 27 Individuals with Two or More Examinations Within One Week

TABLE 14. Uranium Analysis and In Vivo Examination Results

$$
\begin{gathered}
\text { Descending Rank According Descending Rank According } \\
\text { to Percentage of to Percentage of }
\end{gathered}
$$

Mill Urinalyses $\geq 15 \mu \mathrm{g}$ of $\mathrm{U} / \mathrm{\ell} \quad$ in vivo examinations $\geq 8 \mathrm{mg}$ of $\mathrm{U}$

1

7

4

8.5

2

3

4

$5^{(a)}$

2

6

3

6

5

2

7

3

8

8.5

1

9

1

5

(a) For 1979 and 1980. 
Natural uranium provides a unique inherent opportunity to evaluate the accuracy of the in vivo examinations results because approximately $0.7 \%$ of the mass of natural uranium is $235 \mathrm{U}$. Although natural uranium is mostly $238 \mathrm{U}$, the $235 \mathrm{U}$ can easily be measured when in vivo examination results exceed a few milligrams of natural uranium. (Cohen 1977; Spitz et al. 1980) Table 15 compares the amount of ${ }^{238} \mathrm{U}$ and $235 \mathrm{U}$ measured in vivo simultaneously. Even when natural uranium results exceeded $12 \mathrm{mg}$, on $1 y \overline{19} . \overline{1 \%}$ of the $235 \mathrm{u}$ results were greater than zero when, in fact, the expected amount of $235 \mathrm{U}$ that should have been detected was greater than $86 \mu \mathrm{g}$. This amount of $235 \mathrm{U}$ is significantly above $L_{d}$ and should be detected almost $100 \%$ of the time.

Figure 9 is a scattergram of the amount of natural uranium reported versus the amount of $235 \mathrm{U}$. The straight line in Figure 9 represents the expected relationship between natural uranium and $235 \mathrm{U}$ which, apparently, was not achieved.

\section{CORRELATION OF URANIUM URINALYSES, IN VIVO, AND AIR SAMPLER RESULTS}

Guidance from the NRC indicates that air sampling is the primary health physics monitoring tool to detect and measure airborne uranium exposure (USNRC 1978). Uranium urinalyses and in vivo examinations are, therefore, of secondary and tertiary importance, respectively. Furthermore, NRC guidance explains that routine uranium urinalyses are primarily useful in certifying the efficacy of the air sampling program. The adequacy of the NRC position relative to uranium air sampling, urinalyses, and in vivo examinations can be tested by determining whether results from the aforementioned monitoring programs are correlated.

TABLE 15. Relationship Between Natural Uranium and $235 \mathrm{U}$ Measured In Vivo

\begin{tabular}{|c|c|c|c|}
\hline $\begin{array}{c}\text { Natural U } \\
\text { mg }\end{array}$ & $\begin{array}{c}\text { Number of } \\
\text { In Vivo Examinations } \\
\end{array}$ & $\begin{array}{l}\text { Number of In Vivo } \\
\text { Examinations } \frac{\text { where }}{235 \mathrm{U}>0 \mathrm{mg}} \\
\end{array}$ & $\begin{array}{l}\text { Percent of In Vivo } \\
\text { Examinations where } \\
235 \mathrm{U}>0 \mathrm{mg}\end{array}$ \\
\hline 0 & 205 & 9 & 4.4 \\
\hline$>0$ to $<3$ & 161 & 6 & 3.7 \\
\hline 3 to $<4$ & 173 & 12 & 6.9 \\
\hline 4 to $<5$ & 165 & 13 & 7.9 \\
\hline 5 to $<6$ & 170 & 20 & 11.8 \\
\hline 6 to $<8$ & 248 & 37 & 14.9 \\
\hline 8 to $<12$ & 191 & 34 & 17.8 \\
\hline$\geq 12$ & 47 & 9 & 19.1 \\
\hline
\end{tabular}




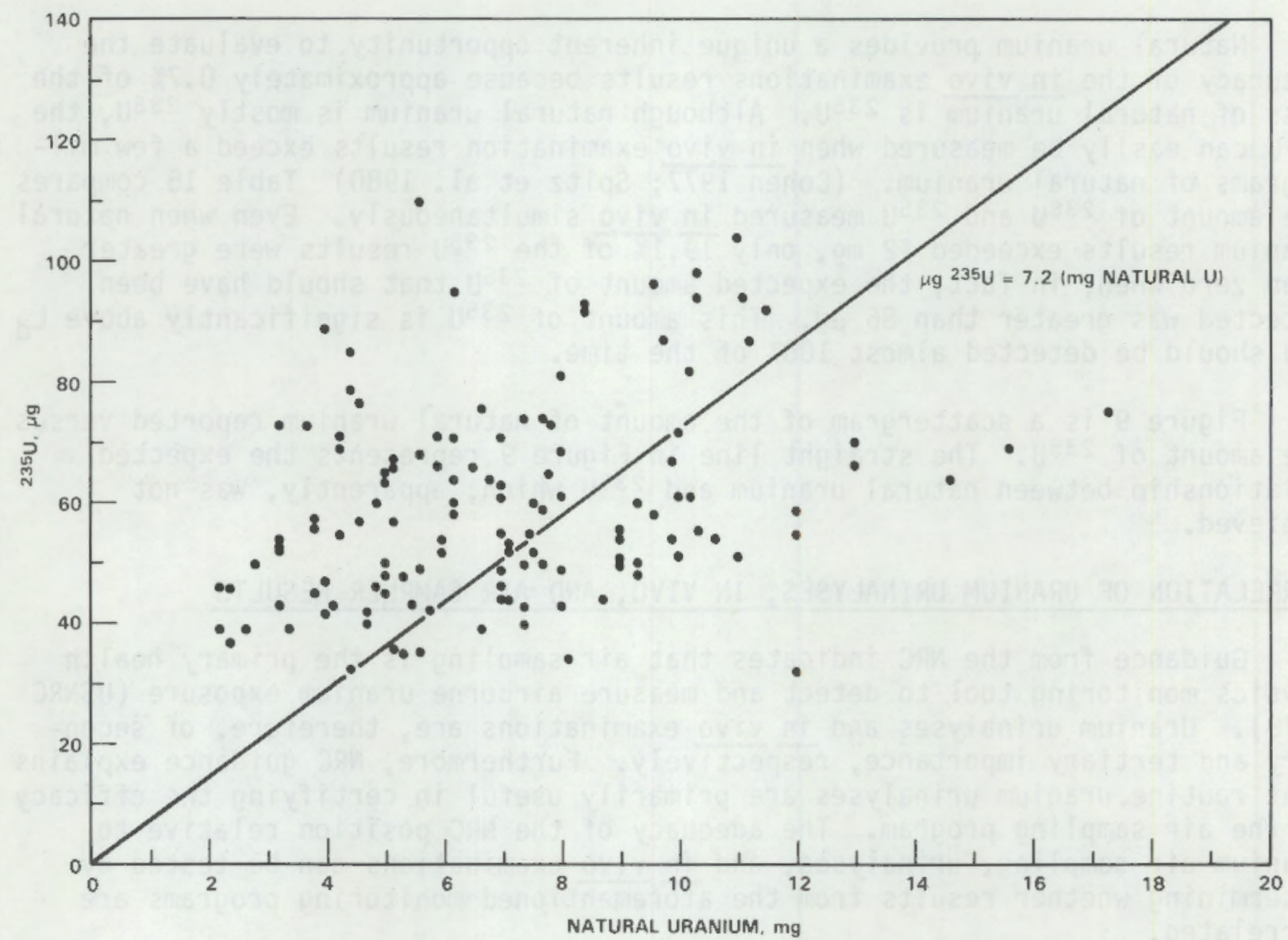

FIGURE 9. Amounts of Natural Uranium in mg Versus Amounts of $235 \mathrm{U}$ in $\mu \mathrm{g}$

Mill 2, which performed routine uranium urinalyses on a monthly basis, also submitted a total of 243 results of personnel air samplers obtained for several individuals. Figure 10 indicates that, for this set of data, no correlation between uranium urinalyses and air sampler results could be found. Measurements of uranium in vivo were also available for these same workers.

The relationship between results of in vivo uranium examinations and a worker's urinalyses or air sampler results was investigated by calculating the correlation coefficient for the in vivo examination result. Six parameters were used:

- mean urinalysis result during previous six months

- highest urinalysis result during previous six months

- urinalysis result nearest the in vivo examination date

- mean air sampler result during previous six months

- highest air sampler result during previous six months

- air sampler result nearest the in vivo examination date.

Table 16 shows the correlation coefficients between the whole body counter examination results and the above parameters for 1978, 1979, and 1980 individually and for all three years combined. For the years individually, only the 


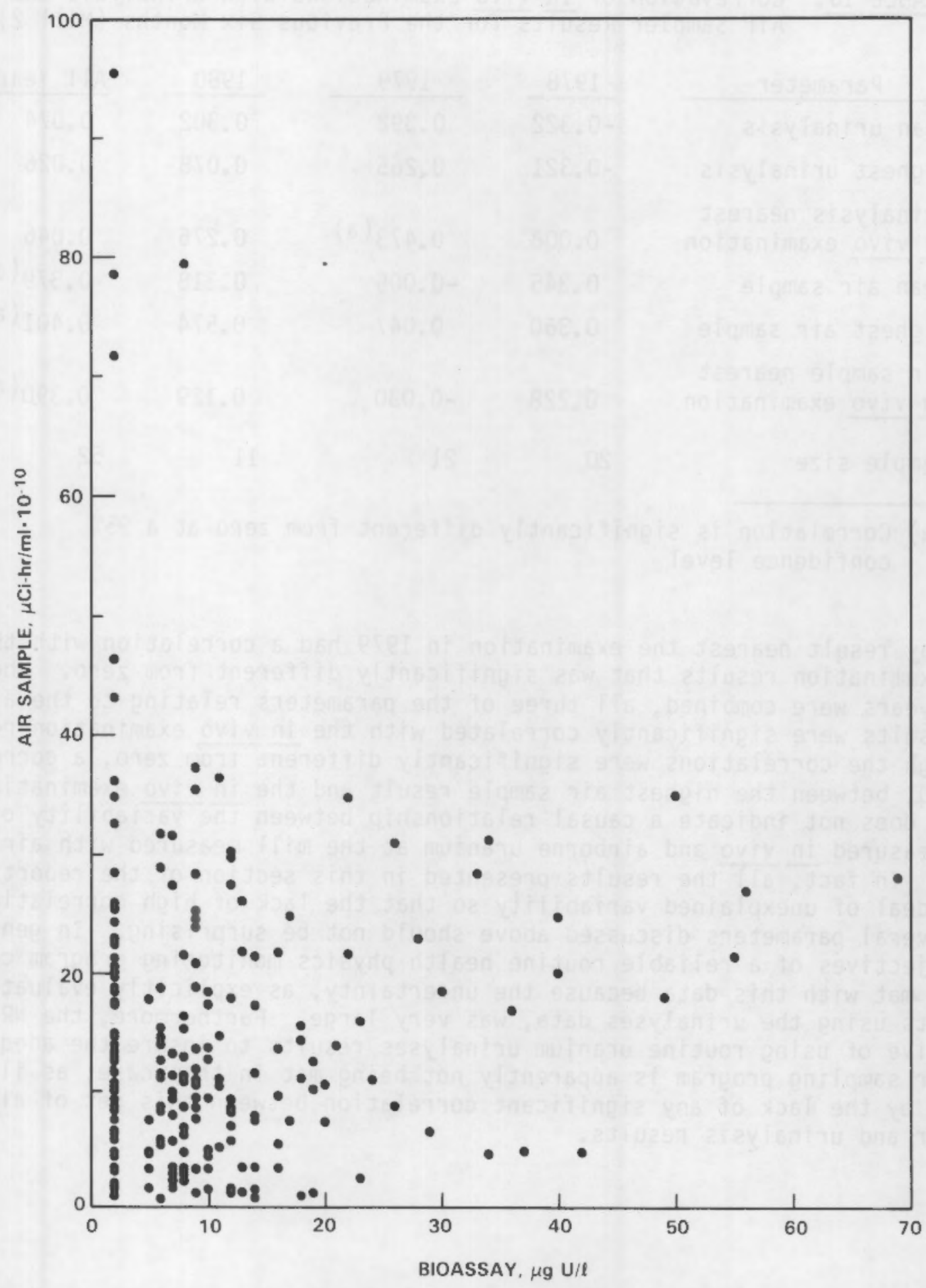

FIGURE 10. Correlation Between Urinalysis and Air Sampler Results for Mill 2 
TABLE 16. Correlation of In Vivo Examinations with Urinalysis and Air Sampler Resuits for the Previous Six Months (Mill 2)

\begin{tabular}{|c|c|c|c|c|}
\hline Parameter & 1978 & 1979 & 1980 & All Years \\
\hline Mean urinalysis & -0.322 & 0.392 & 0.302 & 0.074 \\
\hline Highest urinalysis & -0.321 & 0.265 & 0.078 & 0.026 \\
\hline $\begin{array}{l}\text { Urinalysis nearest } \\
\text { in vivo examination }\end{array}$ & 0.008 & $0.473^{(a)}$ & 0.276 & 0.046 \\
\hline Mean air sample & 0.345 & -0.005 & 0.318 & $0.379(a)$ \\
\hline Highest air sample & 0.360 & 0.047 & 0.574 & 0.401 (a) \\
\hline $\begin{array}{l}\text { Air sample nearest } \\
\text { in vivo examination }\end{array}$ & 0.228 & -0.030 & 0.129 & $0.390(a)$ \\
\hline Sample size & 20 & 21 & 11 & 52 \\
\hline
\end{tabular}

(a) Correlation is significantly different from zero at a $95 \%$ confidence level

bioassay result nearest the examination in 1979 had a correlation with the in vivo examination results that was significantly different from zero. When the three years were combined, all three of the parameters relating to the air sample results were significantly correlated with the in vivo examination results. Although the correlations were significantly different from zero, a correlation of 0.401 between the highest air sample result and the in vivo examination result does not indicate a causal relationship between the variability of uranium measured in vivo and airborne uranium at the mill measured with air samplers. In fact, all the results presented in this section of the report show a great deal of unexplained variability so that the lack of high correlation in the several parameters discussed above should not be surprising. In general, the objectives of a reliable routine health physics monitoring program could not be met with this data because the uncertainty, as explicitly evaluated with BW plots using the urinalyses data, was very large. Furthermore, the NRC objective of using routine uranium urinalyses results to insure the adequacy of the air sampling program is apparently not being met in this case, as illustrated by the lack of any significant correlation between this set of air sampler and urinalysis results. 


\section{DISCUSSION}

Uranium presents both a radiological and chemical hazard to man when it is deposited in the body (Hodge 1956; Eisenbud 1956; Butterworth 1958); therefore, exposure limits are established so that uranium work can be conducted with the risk of health effects kept acceptably low. Once an exposure has occurred, the amount of uranium deposited in the body can be estimated from measurements of uranium in excreta and from in vivo examinations (Scott 1967; Cofield 1960; Alexander 1974; King 1979). Urine and fecal analyses measure the amount of inhaled uranium that has translocated from the lungs and passed through the body. In vivo examinations can determine the amount of uranium deposited in the lungs, kidney, and skeleton. Together, these measurements can be used to determine the amount of uranium initially inhaled and the amount expected to remain in the body as a long-term deposition (Quastel 1970).

\section{PERFORMANCE CRITERIA}

In general, a routine bioassay program should detect uranium with a high degree of confidence so that millworkers who may have unknowingly been exposed on the job are reliably identified by a high urinalysis or an in vivo examination result. No single criterion exists for identifying unknowingly exposed workers; however, the most reliable method is the analysis of excreta from workers who occupy areas of uranium mills where intake is possible (Hursh 1958; Dolphin 1972).

Whenever NRC action levels for bioassay measurement results are exceeded, the mills must respond ( $100 \%$ of the time) with an appropriate action such as investigating the cause of the elevated result or by removing the worker from the area where the exposure likely occurred (USNRC 1978). If bioassay measurements are unreliable, then false positive results may initiate an unnecessary response from the mill and place unnecessary concern upon the worker. On the other hand, false negative results may allow a real uranium intake to go undetected. Both of these should be avoided as much as possible, and the probability of each occurring should be known to those responsible for the monitoring program.

Eliminating all false results is nearly impossible, would place a significant financial burden upon the mill, and would be an inconvenience to the worker because of the type and number of bioassay measurements necessary to achieve perfect reliability (i.e., accurate $100 \%$ of the time). Therefore, within realistic constraints, a known, limited degree of false results may be accepted so long as the probability of missing a serious exposure is zero.

When performance criteria are established, such as the NRC has recommended in a limited fashion in its draft regulatory guidance, guidelines for measurement reliability should be included along with accuracy in terms of bias, precision, and detection limits. The NRC has not considered measurement confidence or reliability in the regulatory guide for bioassay measurements at uranium mills. The required level of confidence depends upon how well the uranium content in the lungs or excreta must be known. The draft NRC 
regulatory guidance implies that uranium mill bioassay programs detect $15 \mu \mathrm{g}$ of $\mathrm{U} / \mathrm{l}$ in urine and $8 \mathrm{mg}$ of $U$ in the lungs with perfect confidence (i.e., 100\% of the time) since there is no guidance to the contrary.

The cost of a bioassay monitoring program depends on sampling or measurements frequency and the laboratory performance. Highly sensitive, highly reliable bioassay measurements are usually more costly. However, fewer samples need be collected relative to a less sensitive, less reliable bioassay measurement to achieve the programmatic objective. In other words, because one procedure is twice as sensitive as another, the mill may be able to satisfy monitoring requirements with one measurement a month rather than two or more, thereby gaining some offsetting cost savings. Another impact resulting from use of bioassay analyses with poor performance may be the number of follow-up analyses necessary because of the high frequency of false positive results. The impact arising from the number of false negative results is unmeasureable.

Thus, there is a trade-off between level of performance (including accuracy in terms of bias, precision, and reliability) and monitoring frequency. Once suitable performance criteria are achieved, the credibility of the monitoring program, for the mills, its employees, and the NRC, is well established.

\section{URINALYSIS RESULTS}

The large variability observed in the urinalyses data may be a result of collecting single void urine samples which, after analysis, are adjusted in volume to represent that amount of urine excreted by reference man in one day (ICRP 1975). This adjustment is not necessarily the correct approach since metabolism varies significantly from worker to worker. Furthermore, excretion of internally deposited radioactive materials fluctuates widely with time. For example, urine excreted after arising from sleep usually contains the highest content of metabolites, including uranium (Dolphin 1972).

The urinalysis quality control programs conducted at a few mills involved a practice that might have introduced a bias to our analysis of test urine sample results. Some spiked test samples were produced by adding a known amount of uranium activity to an aliquot of urine obtained from a worker's actual routine sample rather than using urine from a person known to have no exposure to uranium at the mill. Whenever such urine was used for a spiked test sample, the results had to be "adjusted" by subtracting the amount of known added activity from the measured result. This practice would have an impact on this mill's quality control program by significantly increasing the uncertainty of the spiked test sample results whenever the urine used as a blank was contaminated with uranium. We do not know whether data submitted for our analysis was adjusted whenever necessary.

Recognizing that the uranium urinalysis data in this report were unreliable, the result records were examined to determine whether the retention of uranium in mill workers could be determined from a graph of uranium excretion with time. Since urinalysis test data indicate that no mill should fail to detect $30 \mu \mathrm{g}$ of $\mathrm{U} / \mathrm{l}$, individuals with at least one result exceeding this value were identified using a computer search of the data records. There were 
256 workers out of 1369 with at least one urinalysis result exceeding $30 \mu \mathrm{g}$ of $\mathrm{J} / 2$. However, only 12 workers had adequate follow-up sampling from which retention could be evaluated. Apparently, this lack of diagnostic sampling was due, in part, to the delay between sample collection, analysis, and notification to the mill.

Figures 11 and 12 show uranium urinalysis data for two workers with at least one result greater than $35 \mu \mathrm{g}$ of $\mathrm{U} / \ell$. The urinalysis results are plotted against consecutive days starting with the first available result in the record. Results below $5 \mu \mathrm{g}$ of $\mathrm{U} / \mathrm{l}$, the dashed line on the plot, are not shown. The mean observed half-time for uranium in twelve different workers was $14.6 \pm$ 4.3 days. It is not known what systemic retention compartment this represents or whether there is more than one compartment represented by this data. However, according to ICRP 30 (ICRP 1979), three compartments are expected (viz., bone, kidney, and soft tissue). These are in addition to deposition sites in the respiratory system.

Graphical analysis is a useful technique for identifying and evaluating trends. For example, Figures 13 and 14 illustrate an unusual trend in the results of routine urinalyses for two workers at Mill 10. Apparently near day 450, something happened at Mill 10 to reduce the amount of uranium inhaled by these workers as demonstrated by reduction of uranium excreted in urine. The variability of the results also appears significantly reduced. Although no explanation for the change was available in the records, the management at Mill 10 may have changed the urinalyses laboratory or procedure, improved a milling process, or inplemented a respirator program. It is unusual that results and their variability could experience a change of this magnitude without a concurrent action from management. Had the urinalysis results been examined for trends, managenent would have noticed the change and could have taken steps to document its findings for the records. This documentation would be essential if the observed trend proved to represent a possible increase in worker exposure rather than a diminution, as illustrated in Figures 13 and 14.

Figure 15 illustrates an unexpected event at a uranium mill processing yellowcake that is dried at high temperatures and, therefore, expected to exhibit insoluble characteristics in the lung and a long, effective clearance halftime in the respiratory tract. The first and last peaks in the figure represent uranium concentrations of $285 \mu \mathrm{g}$ of $\mathrm{U} / \ell$ and $580 \mu \mathrm{g}$ of $\mathrm{U} / \ell$, respectively with clearance half-times equal to 3.3 days and 1.8 days, respectively. The observed peaks may not be due to uranium intakes, but rather contamination of the sample. Sample contamination would be likely if the monitoring program required sample collection during the work day when the millworkers were on the job. No explanation was available in this worker's records to describe the occurrence.

\section{IN VIVO EXAMINATION RESULTS}

Analysis of in vivo examination results determined that variations observed between sequential measurements were significantly greater than expected. In addition, the fact that the highest in vivo lung measurement 


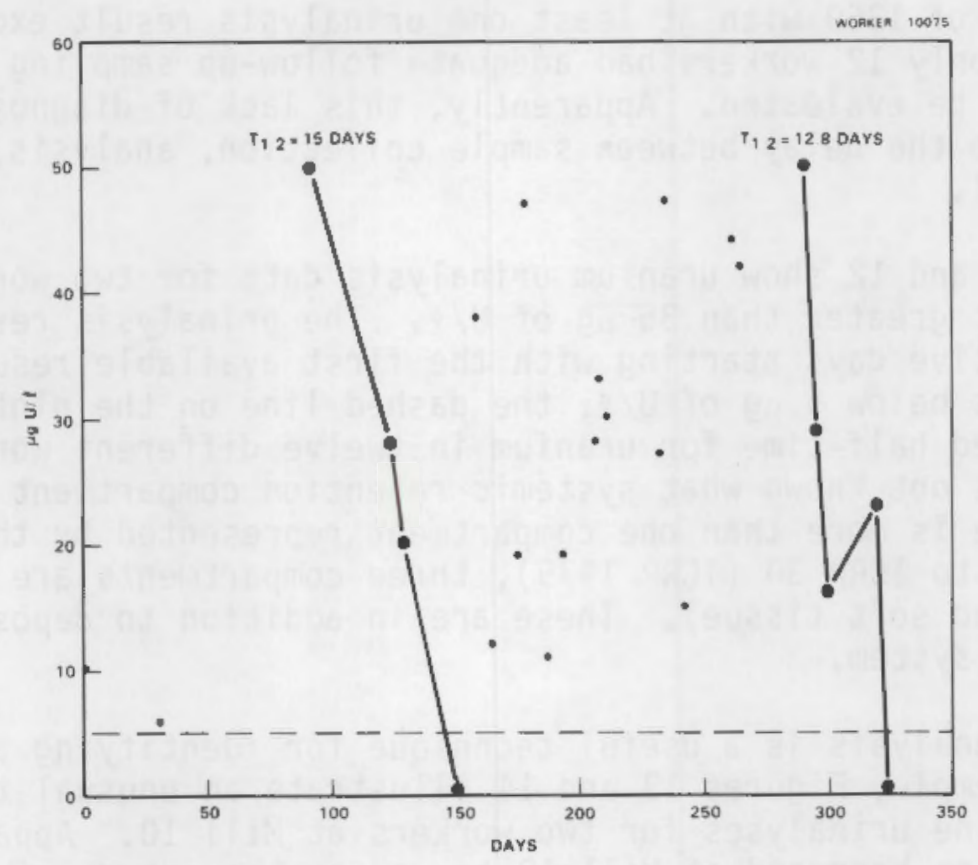

FIGURE 11. Detailed Routine Results for Uranium in Urine of Worker A

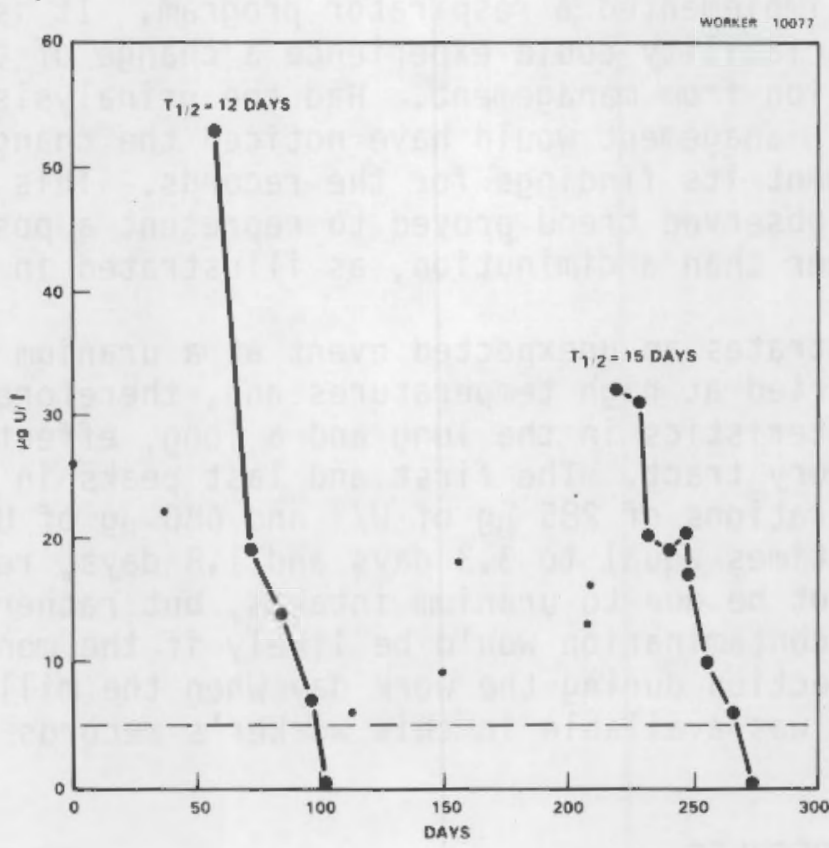

FIGURE 12. Detailed Routine Results for Uranium in Urine of Worker B 


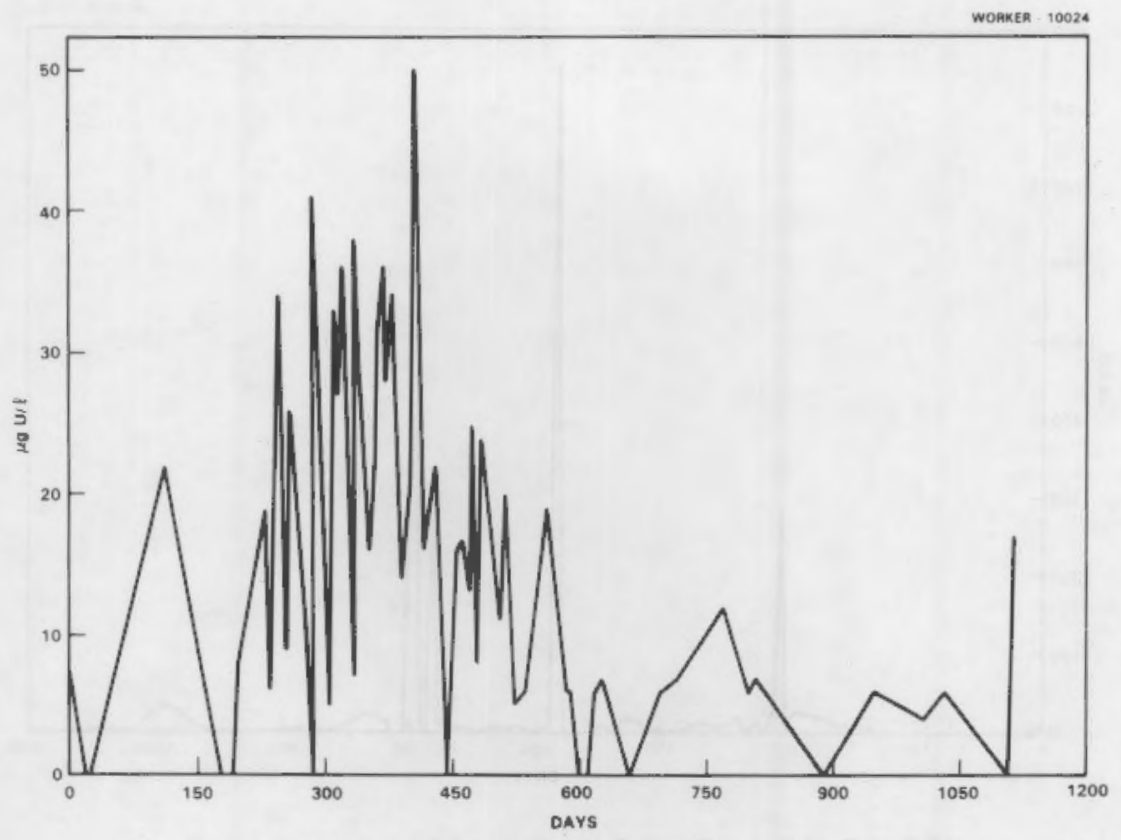

FIGURE 13. Routine Results for Uranium in Urine of Worker C

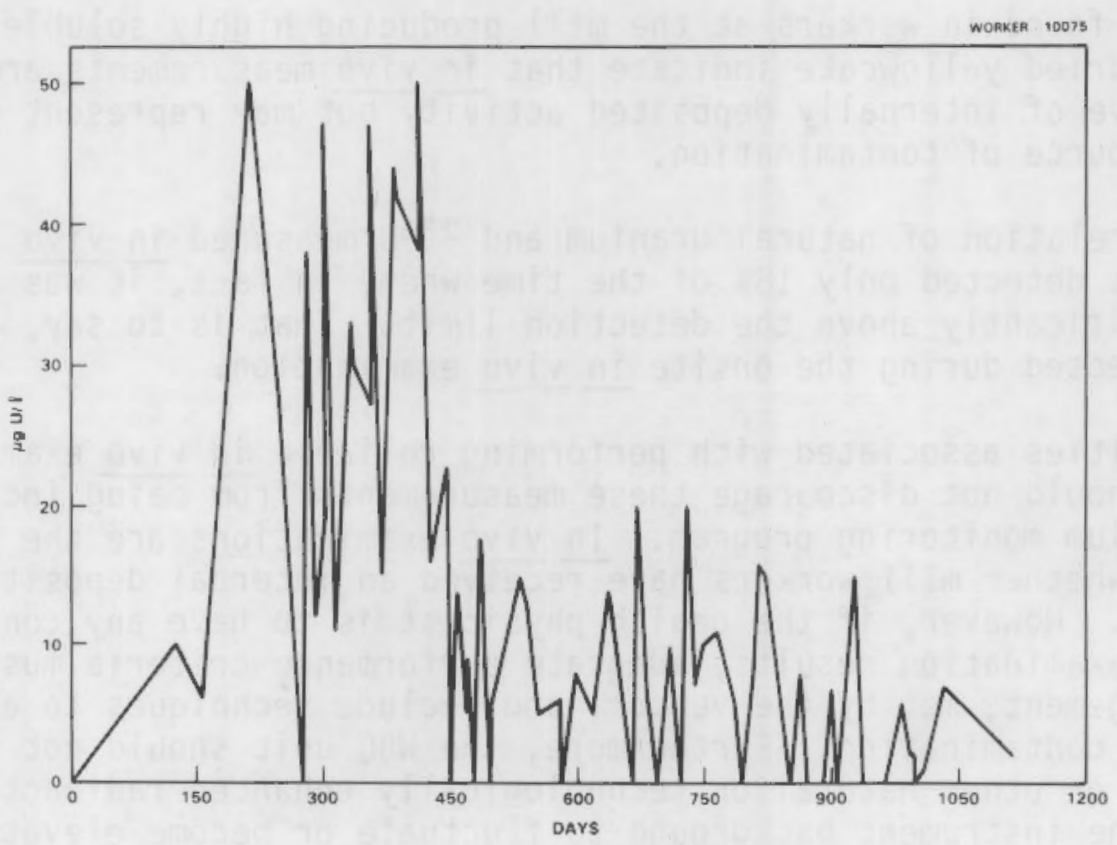

FIGURE 14. Routine Results for Uranium in Urine of Worker A 


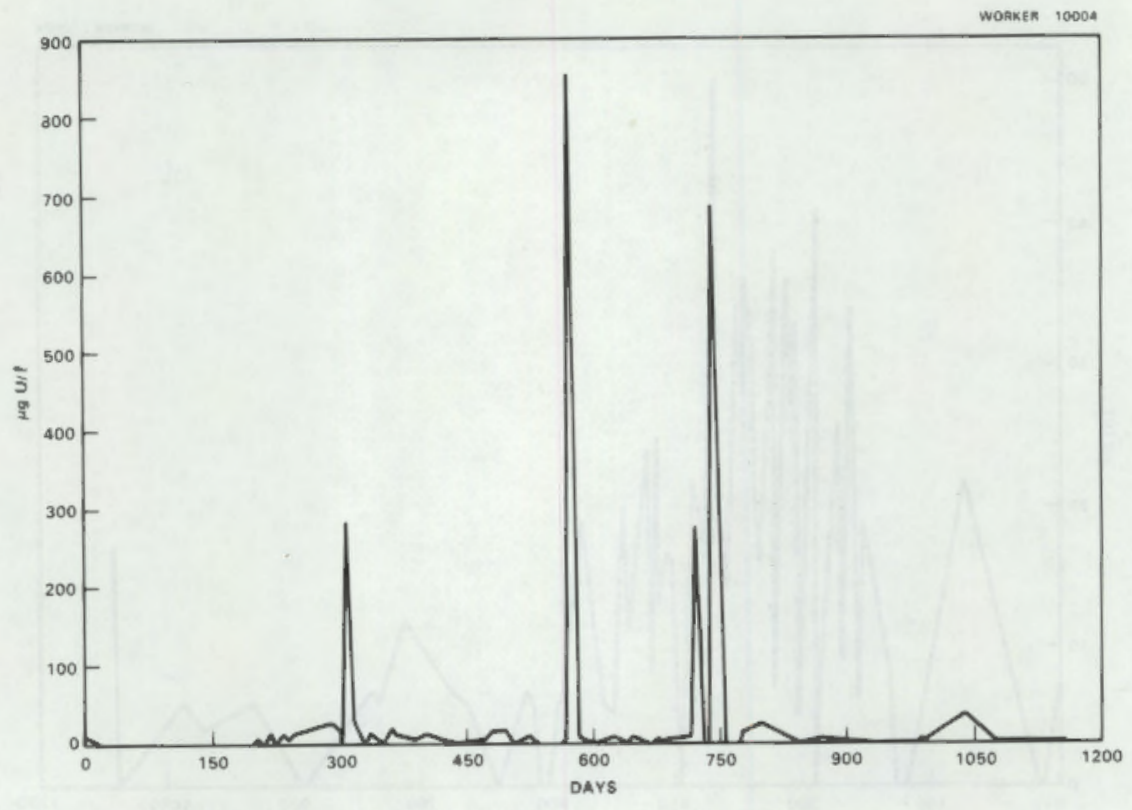

FIGURE 15. Routine Results for Uranium in Urine of Worker D

results were found in workers at the mill producing highly soluble, lowtemperature-dried yellowcake indicate that in vivo measurements are probably not indicative of internally deposited activity but may represent surface or some other source of contamination.

The correlation of natural uranium and $235 \mathrm{U}$ measured in vivo indicated that $235 \mathrm{U}$ was detected only $18 \%$ of the time when, in fact, it was present in amounts significantly above the detection limit. That is to say, $235 \mathrm{U}$ was not reliably detected during the onsite in vivo examination.

Difficulties associated with performing reliable in vivo examinations at mill sites should not discourage these measurements from being included in a routine uranium monitoring program. In vivo examinations are the only means of determining whether mill workers have received an internal deposition of insoluble uranium. However, if the health physicist is to have any confidence in the in vivo examination results, adequate performance criteria must be adopted by miTl management, met by the vendor, and include techniques to account for uranium skin contamination. Furthermore, the WBC unit should not be located near uranium or other natural or technologically enhanced radioactive materials that cause the instrument background to fluctuate or become elevated (Spitz et al. 1980; Shapiro 1974; Helgeson 1979).

A comparison of uranium urinalyses and in vivo examination results was made by ranking the results according to the percentage at each mill that exceed the NRC action levels. Mills with the highest percentage of urinalysis results above action limits did not have the highest percentage of in vivo examination results above the action limits. There were no significant correlations between uranium urinalysis or in vivo examination results for any 
mill. In fact, expected differences in bioassay monitoring results between mills producing high- and low-temperature-dried yellowcake were not observed. 


\section{CONCLUSIONS}

The bioassay results in our study, involving the period from 1978 through 1980, were highly variable and thus unreliable as a monitoring tool for determining whether millworkers have been exposed to airborne uranium. Health physicists at these mills during this period were apparently unaware of this variability and its impact upon reliability because, heretofore, the bioassay data had never been analyzed to determine its quality. Furthermore, the manner in which bioassay result records were maintained on file at the uranium mills was not conducive to any type of trend analysis.

The NRC should consider establishing uniform performance criteria for uranium bioassay monitoring results and recommending explicit levels of accuracy in terms of bias, precision, and confidence that should be achieved by these routine measurements. Application of uniform bioassay performance criteria at all mills would simplify interpretation of results from mill to mill. In lieu of new recommendations, the only performance criteria currently recognized by the mills or their in-plant or vendor laboratories are those recommendations cited in the draft NRC Regulatory Guide 8.22 (USNRC 1978) which sets $5 \mu \mathrm{g} \mathrm{U} / 1$ as the measurement sensitivity. Lacking such regulatory guidance, bioassay results may continue to be unreliable. Therefore, the draft NRC regulatory guidance should be revised and issued to include as performance criteria, explicit recommendations for the levels of accuracy in terms of bias, precision, and confidence expected from bioassay monitoring results.

Once performance criteria for accuracy, precision, and confidence are adopted and implemented, a routine procedure for uranium mill health physicists to test bioassay processors will be required to insure that the performance criteria are reliably being met. The recommended procedure involves preparation of urine samples that contain known quantities of uranium and blanks that the health physicist would submit routinely as blinds. Results of these tests would enable health physicists at each mill to calculate decision limits ( $L_{C}$ ) and detection limits $\left(L_{d}\right)$ and determine how well bioassay performance criteria are being met. Recommendations for bioassay performance criteria and a program to test the laboratory are given in Appendix B.

The observed retention half time of uranium in the body of exposed millworkers in this study is approximately 14 days. Urine samples collected less frequently than twice a month may fail to detect an unknowingly exposed worker because of the apparent rapid clearance of uranium from the body. Furthermore, if bioassay results continue to be unreliable, the sampling frequency may need to be greater than semimonthly. On the other hand, a bioassay monitoring program with sensitive, highly reliable procedures might enable samples to be collected less frequently than twice a month.

The quality of in vivo examination results could not be determined directly as it was for results of urinalyses. However, measurement variability was found to be very large, limiting in vivo examinations as a useful bioassay monitoring tool. Some of the measurement variability was likely due to the influence of large quantities of radioactive milling by-products in close 
proximity to the mobile $\mathrm{WBC}$, uranium dust in the air, and uranium contamination on the skin or hair of the workers being examined. Although significant environmental factors present at the mill apparently caused the in vivo examination results to be unreliable, in vivo examinations should not be abandoned as a monitoring tool for uranium mill workers. Improved, and potentially useful, results can likely be obtained by minimizing the effects of environmental factors.

Two recommendations are proffered to improve the in vivo results. First, uranium contamination on the skin can be quantitatively determined by measuring the low-energy uranium $x$-rays emitted by activity on the surface of the body and eliminating that uranium from the total measured in vivo. Examinations performed with thin, dual-crystal scintillation detectors or high resolution, solid state, planar, germanium detectors can simultaneously measure the uranium $x-r a y$ as photons and uranium to determine the amount deposited in the lungs. Secondly, regional WBC examination centers could be established in areas close to uranium milling areas. These permanent centers would be able to control ambient conditions and interferences, such as contaminated surface dust on workers, more consistently than is apparently possible with onsite measurements. A combination of these two recommendations would best suit requirements for in vivo examination of uranium mill workers.

The way in which the uranium mills keep and maintain their records needs to be improved. Each mill had its own method for storing bioassay data which in no case was in a form suitable for performing statistical analyses. Furthermore, what data were stored typically were incomplete and lacked explicit information about the sample collection date, the processing date, who performed the analyses, and whether the result was valid. A sample copy of data from each mill is provided in Appendix A. Revisions to the draft NRC regulatory guidance should provide guidance relative to the minimum data elements for retention in permanent records and the manner in which data should be saved. The only way in which the mills and the NRC can determine whether regulations concerning uranium exposure have been met is to evaluate the records containing bioassay results. These records must be complete and in a format such that the data are easily retrievable. 


\section{REFERENCES}

Alexander, R. E. 1974. Applications of Bioassay of Uranium. WASH-1241, U.S. Atomic Energy Commission, Washington, D.C.

Butterworth, A. 1958. "Human Data on Uranium Exposure," In Symposium on Occupational Health Experience and Practices in the Uranium Industry, HASL-58, U.S. Atomic Energy Commission, Washington, D.C.

Cofield, R. E. 1960. "In Vivo Gamma Counting as a Measurement of Uranium in the Human Lung." Health Physics. 2:269.

Cohen, N., H. B. Spitz, and M. E. Wrenn. 1977. "Estimation of Skeletal Burden of 'Bone-Seeking' Radionuclides in Man from In Vivo Scintillation Measurements of the Head." Health Physics. 33:431.

Currie, L. A. 1968. "Limits for Qualitative Detection and Quantitative Determination." Analytical Chemistry. 40:586.

Dolphin, G. W. 1972. "Some Problems in Interpretation of Bioassay Data", In Proceedings of the Symposium on Assessment of Radioactive Organ and Body Burdens. IAEA-SM-150156, Vienna.

Eidson, A. F., and J. A. Mewhinney. 1980. "In Vivo Solubility of Yellowcake Samples from Four Uranium Mills and the Implications for Bioassay Interpretation." Health Physics. 39:893.

Eisenbud, M., and J. Quigley. 1956. "Industrial Hygiene of Uranium Processing." AMA Arch. Ind. Health. 14:12.

Helgeson, G. L. 1979. "In Vivo Counting at Selected Uranium Mills." NUREG/CR-0841, U.S. NucTear Regulatory Commission, Washington, D.C.

Hodge, H. C. 1958. "Mechanism of Uranium Poisoning." A.M.A.Arch. Ind. Health. $14: 43$.

Hursh, J. B. 1958. "Urinary Uranium as an Indicator of Dose to Exposed Personnel," In Symposium on Occupational Health Experience and Practices in the Uranium Industry. HASL-58, U.S. Atomic Energy Comission, Washington, D.C.

International Commission on Radiological Protection (ICRP). 1968. ICRP Publication 10, Evaluation of Radiation Doses to Body Tissues from Internal Contamination Due to Occupational Exposure. Pergamon Press, New York, New York.

International Commission on Radiological Protection (ICRP). 1975. ICRP Publication 23, Report of the Task Group on Reference Man. Pergamon Press, New York, New York. 
International Commission on Radiological Protection (ICRP). 1979. ICRP Publication 30 , Part 1. Limits for Intakes of Radionuclides by Workers. Pergamon Press, New York, New York.

Kalkwarf, D. R. 1979. "Solubility Classifications of Airborne Products from Uranium Ores and Tailings Piles." NUREG/CR-530, USNRC, Washington, D.C.

King, W. C. 1979. Bioassay at Uranium Mills: A Discussion of Nuclear Regulatory Commission Regulatory Guide 8.22. UCID-18027, Lawrence Livermore Laboratory, Livermore, California.

Natrella, M. G. 1966. Experimental Statistics, Chapter 17. National Bureau of Standards Handbook \#91, Washington, D.C.

Quastel, M. R., et al. 1970. "Excretion and Retention by Humans of Chemically Inhaled Uranium Dioxide." Health Physics. 18:233.

Quigley, J. A., R. C. Heatherton, and J. F. Ziegler. 1958. "Studies of Human Exposure to Uranium." Paper presented at the Symposium on 0ccupational Health Experience and Practices in the Uranium Industry, October 15-17. (Can also be found as U.S. Atomic Energy Commission Health and Safety Laboratory Report, HASL-58, Washington, D.C.)

Scott, L. M., and C. M. West. 1967. "An Evaluation of $\mathrm{U}_{3} \mathrm{O}_{8}$ Exposure with an Estimate of Systemic Body Burden." Health Physics. 13:21.

Shapiro, E. G., and A. L. Anderson. 1974. "Dual Energy Analysis Using Phoswich Scintillation Detectors for Low-Level In Vivo Counting." IEEE Transactions on Nuclear Science, NS-21, 201.

Spitz, H. B., et al. 1980. "Investigation of the Solubility of Yellowcake in the Lung of Uranium Mill Yellowcake Workers by Assay for Uranium in Urine and In Vivo Photon Measurements of Internally Deposited Uranium Compounds." In Proceedings of the Fifth International Congress of the International Radiation Protection Association. Pergamon Press, New York, New York.

U.S. Nuclear Regulatory Commission (USNRC). Draft Regulatory Guide 8.22. "Bioassay at Uranium Mills". Single copies are availabTe from USNRC Division of Technical Information and Document Control, Washington, D.C.

Welford, G. A., and R. Baird. 1967. "Uranium Levels in Human Diet and Biological Materials." Health Physics. 13:1321.

Welford, G. A., R. S. Morse, and J. S. Alercio. 1960. "Urinary Uranium Levels in Non-Exposed Individuals." American Industrial Hygiene Assn. Journal. $21: 68$. 

EXAMPLES OF RAW DATA SUBMITTED BY THE URANIUM MILLS 


\section{BIO ASSAY PROGRAM}

NAME $\quad$ S.S. No. $\quad$ DATE OF BIRTH: ${ }^{10-3-43}$ WORK Na: $\frac{00272}{-}$

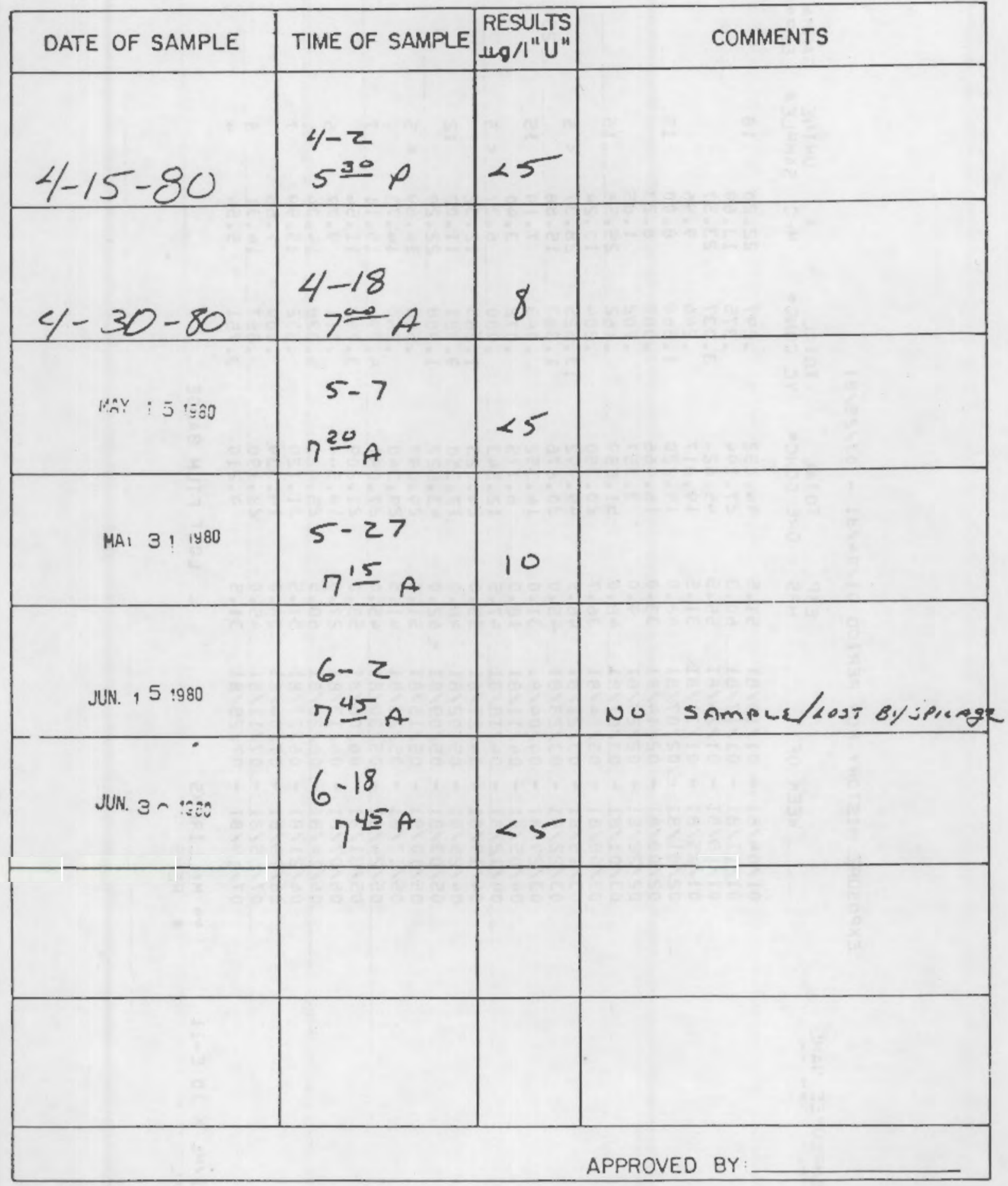


EXPOSURE HISIORY FOR PERIOO $01 / 04 / 41$ - 01/25/91

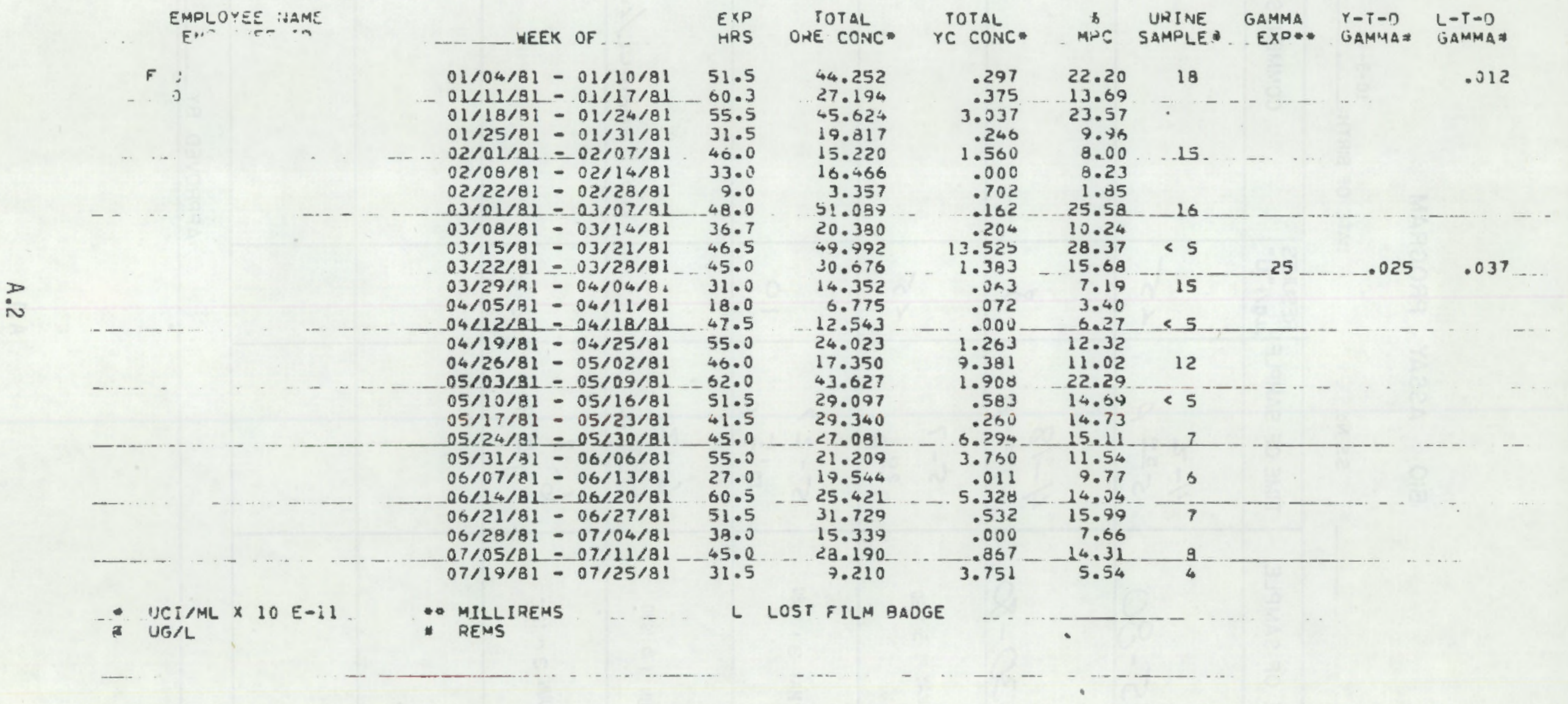


3RO QUARTER 1979

\begin{tabular}{|c|c|c|c|c|}
\hline I.D. \# & Dates of Urine & $\begin{array}{c}\text { Urinalysis } \\
\text { U(Mg)D }\end{array}$ & $\begin{array}{c}9 / 23 / 79-9 / ? 9 / 79 \\
\mathrm{YC}\left(\mathrm{mghr} / \mathrm{m}^{3}\right) \\
\end{array}$ & $\begin{array}{c}9 / 16 / 79-9 / 22 / 79 \\
\mathrm{YC}\left(\mathrm{mghr} / \mathrm{m}^{3}\right)\end{array}$ \\
\hline 2 & $9 / 24 / 79$ & 5.0 & 0.04 & 0.10 \\
\hline 182 & $9 / 24 / 79$ & 3.6 & 0.03 & 0.02 \\
\hline 160 & $9 / 24 / 79$ & 6.1 & 0.00 & 0.00 \\
\hline 17 & $9 / 24 / 79$ & $<1.8$ & 0.02 & 0.03 \\
\hline 219 & $9 / 24 / 79$ & $<2.2$ & 0.03 & 0.02 \\
\hline 37 & $9 / 24 / 79$ & 6.2 & 0.07 & 0.32 \\
\hline 155 & $9 / 24 / 79$ & 2.1 & 0.03 & 0.03 \\
\hline 163 & $9 / 24 / 79$ & 3.2 & 0.00 & 0.00 \\
\hline 121 & $9 / 24 / 79$ & $<1.9$ & 0.00 & 0.00 \\
\hline 177 & $9 / 24 / 79$ & 5.9 & 0.06 & 0.11 \\
\hline 152 & $9 / 24 / 79$ & 2.3 & 0.00 & 0.00 \\
\hline 172 & $9 / 24 / 79$ & 2.6 & 0.03 & 0.03 \\
\hline 171 & $9 / 24 / 79$ & $<2.1$ & 0.03 & 0.16 \\
\hline $15 i$ & $9 / 24 / 79$ & $<2.2$ & 0.00 & 0.00 \\
\hline 170 & $9 / 24 / 79$ & 2.3 & 0.04 & 0.13 \\
\hline 71 & $9 / 24 / 79$ & $<3.1$ & 0.03 & 0.02 \\
\hline 82 & $9 / 24 / 79$ & $<3.1$ & 0.03 & 0.03 \\
\hline 173 & $9 / 24 / 79$ & $<3.1$ & 0.00 & 0.00 \\
\hline 84 & $9 / 24 / 79$ & 4.4 & 0.01 & 0.12 \\
\hline 167 & $9 / 24 / 79$ & $<1.8$ & 0.02 & 0.04 \\
\hline 102 & $9 / 24 / 79$ & $<1.8$ & 0.00 & 0.00 \\
\hline 221 & $9 / 24 / 79$ & $<1.8$ & 0.00 & 0.00 \\
\hline
\end{tabular}


NATURAL

URANI UM

$U-235$ NANOCURIES MICROGRAMS

$\begin{array}{llll}-7486 & 07 / 25 / 81 & \text { AT } & 1955 \\ -6932 & 07 / 29 / 81 & \text { AT } & 1045 \\ -4937 & 07 / 26 / 81 & \text { AT } & 0505 \\ -9717 & 07 / 28 / 81 & \text { AT } & 1020 \\ -3779 & 07 / 28 / 81 & \text { AT } & 0741 \\ -3749 & 07 / 25 / 81 & \text { AT } & 2130 \\ -8228 & 07 / 26 / 81 & \text { AT } & 1105 \\ -5263 & 07 / 28 / 81 & \text { AT } & 1350 \\ -4815 & 07 / 26 / 81 & \text { AT } & 0527 \\ -2380 & 07 / 27 / 81 & \text { AT } & 1133 \\ -5967 & 07 / 26 / 81 & \text { AT } & 0521 \\ -0763 & 07 / 27 / 81 & \text { AT } & 0751 \\ -6599 & 07 / 26 / 81 & \text { AT } & 0819 \\ -2852 & 07 / 27 / 81 & \text { AT } & 1440\end{array}$

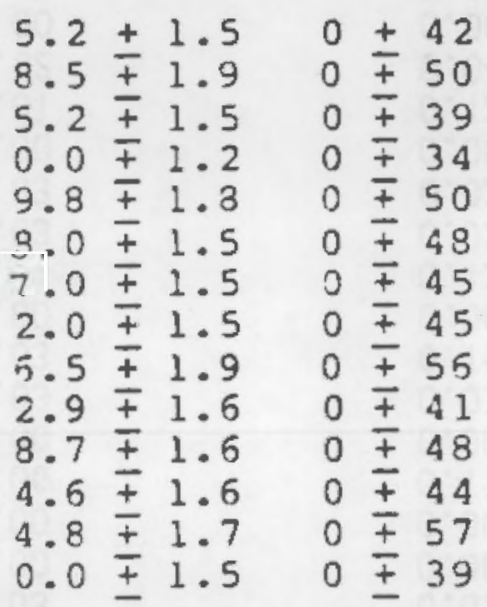

RADIUM B, C NANOCUR IES

$1-534007 / 28 / 81$ AT 1359 $1-377907 / 28 / 81$ AT 1303 :-3749 $07 / 29 / 81$ AT 1024
$3+3$
$3 \mp 2$
$5 \pm 3$ 


\begin{tabular}{|c|c|c|c|c|}
\hline & & & In-Vivo Ana & \\
\hline Bioassay Date & Vendor Report Date & $\begin{array}{c}\text { Urinalysis } \\
\text { Result - un/1 }\end{array}$ & $\begin{array}{c}\text { U-nat } \\
\text { nCi }\end{array}$ & $\begin{array}{c}u-235 \\
u g \\
\end{array}$ \\
\hline $3-13-78$ & & $\angle 5$ & & \\
\hline $2-23-78$ & & & $2 \pm 3$ & $</ 3$ \\
\hline $2-25 \cdot 78$ & & $<5$ & & \\
\hline $2-25-78$ & & $10 \pm 5$ & & \\
\hline $8-79$ & & 3.6 & & \\
\hline $7-11-79$ & & & $4.2 \pm 1.6$ & $0 \pm 50$ \\
\hline $2-11-72$ & & & $2.7 \pm 1.4$ & $0 \pm 47$ \\
\hline $3-80$ & & 8 & & \\
\hline $7-29-80$ & & & $2.3 \pm 1.6$ & $0 \pm 41$ \\
\hline & & & & \\
\hline & & & & \\
\hline & & & & \\
\hline & & & & \\
\hline & & & & \\
\hline & & & & \\
\hline & & & & \\
\hline & & & & \\
\hline & & & & \\
\hline & & & & \\
\hline & & & & \\
\hline & & & & \\
\hline
\end{tabular}


TERSON \#3L

Siluele Llawillir Areas

In Vivo Countmag

$14802.9 \pm 1.2$ NUI UINAT

$0 \pm 29$ MicizogRAMS U-235

Lirine Analusis

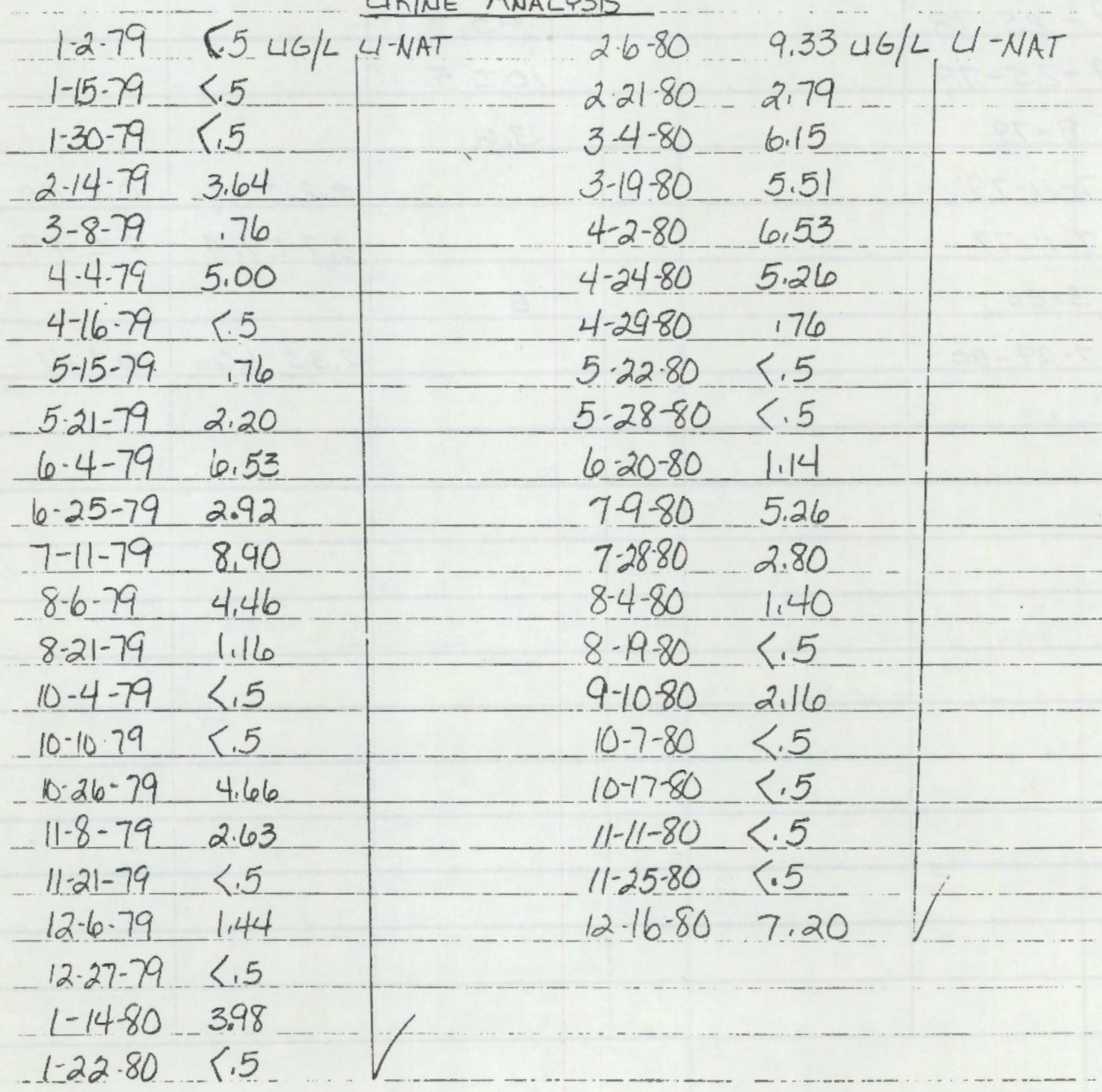

A. 6 
URINE ANALYSIS

may 1979

\begin{tabular}{|c|c|c|c|c|c|c|c|c|c|}
\hline _NAME & & DATE & AREA & ugm $\mathrm{U}^{\mathrm{Nat} /}$ ? & NAME & & DATE & AREA & ugm $U^{\text {Nat/ }} 1$ \\
\hline $\mathrm{T}_{1}$. & 2 & $5 / 3$ & Shifter & 2.33 & & & $5 / 10$ & Shifter & .79 \\
\hline He: & 0.5 .5 & $5 / 4$ & Precip. & 1.74 & & $\Rightarrow$ & $5 / 10$ & Precip & 1.57 \\
\hline Dri & $\mathrm{csc}$ & $5 / 3$ & Filtero & 3.62 & & $0: 8$ & $5 / 10$ & Filtert. & .63 \\
\hline CaI & 058 & $5 / 3$ & Ballmill & 4.64 & & $r: 2$ & $5 / 10$ & BallMill & .63 \\
\hline$\underline{S t}$ i & $y_{1}^{\prime} ;$ & $5 / 3$ & Crush.o & 6.20 & & 029 & $5 / 10$ & Labor & 1.26 \\
\hline Ch. & 060 & $5 / 3$ & Crush.H & 2.59 & & o., & $5 / 10$ & Filter 0. & .94 \\
\hline Me & 054 & $5 / 4$ & Dryer & 1.93 & & $\therefore$ & $5 / 10$ & Crush.H & 1.57 \\
\hline $\mathrm{Me}$ & 054 & $5 / 21$ & Dryer. & 3.44 & & $300 \%$ & $5 / 10$ & pryer & 1.26 \\
\hline Ch & 600 & $5 / 31$ & Crush H & 5.12 & & 303 & $5 / 10$ & Erush.d & 1.57 \\
\hline st & $y \in b^{\prime}$ & & Crush o & Term. $5 / 13$ & & 3006 & $5 / 29$ & pryer & 3.53 \\
\hline Mo & $\cdots$ & & Labor & So Samples & & $C: 11$ & $5 / 31$ & Erush 7 . & 4.53 \\
\hline F: & $\because 2$ & & Filter & $"$ & & 008 & $5 / 31$ & Erush q. & 6.30 \\
\hline- & & & & & & & & & \\
\hline Fr & $0: 3$ & $5 / 7$ & Shifter & 2.30 & & $24:$ & $5 / 14$ & shifter & 1.76 \\
\hline Je & 0,17 & $5 / 7$ & Precip & 6.61 & & 046 & $5 / 14$ & Precip & 3.93 \\
\hline Ev & $0 / 6$ & $5 / 7$ & Filter $\oint$ & 4.31 & & $\because 4$ & $5 / 14$ & Filter 0. & 1.32 \\
\hline La & 020 & $5 / 7$ & BallMil & 1.15 & & 3043 & $5 / 14$ & BallMill & 6.32 \\
\hline Mc & 0.4 & $5 / 17$ & FilterH & 1.45 & & 244 & $5 / 14$ & EilterH. & .88 \\
\hline Ca & 037 & $5 / 7$ & Labor & 2.30 & & 03.5 & $5 / 14$ & fabor & 3.82 \\
\hline$\underline{R}$ & $3:$ & $5 / 7$ & Crush o & .86 & & 023 & $5 / 15$ & Crush of & 3.10 \\
\hline Str & $5 i$ & $5 / 7$ & Crush $\mathrm{H}$ & 2.87 & & +17 & $5 / 15$ & Crush $\mathrm{H}$ & 3.52 \\
\hline$\Gamma \subseteq$ & 032 & $5 / 8$ & Dryer & 1.73 & & $203 !$ & $5 / 14$ & Dryer & 3.97 \\
\hline גU & $\therefore \div$ & $5 / 17$ & Crush o & 1.03 & & 23 & $5 / 29$ & crush of & 2.87 \\
\hline Sh & ars & $5 / 18$ & Crush H & 7.31 & & $\cdots ?$ & $5 / 29$ & Crush H & .66 \\
\hline$\Gamma$ & $\therefore \therefore$ & $5 / 17$ & Dryer & 1.03 & & O3: & $5 / 29$ & Dryer & 2.21 \\
\hline$P C=15$ & $U^{N}$ & & & & & & & & \\
\hline
\end{tabular}




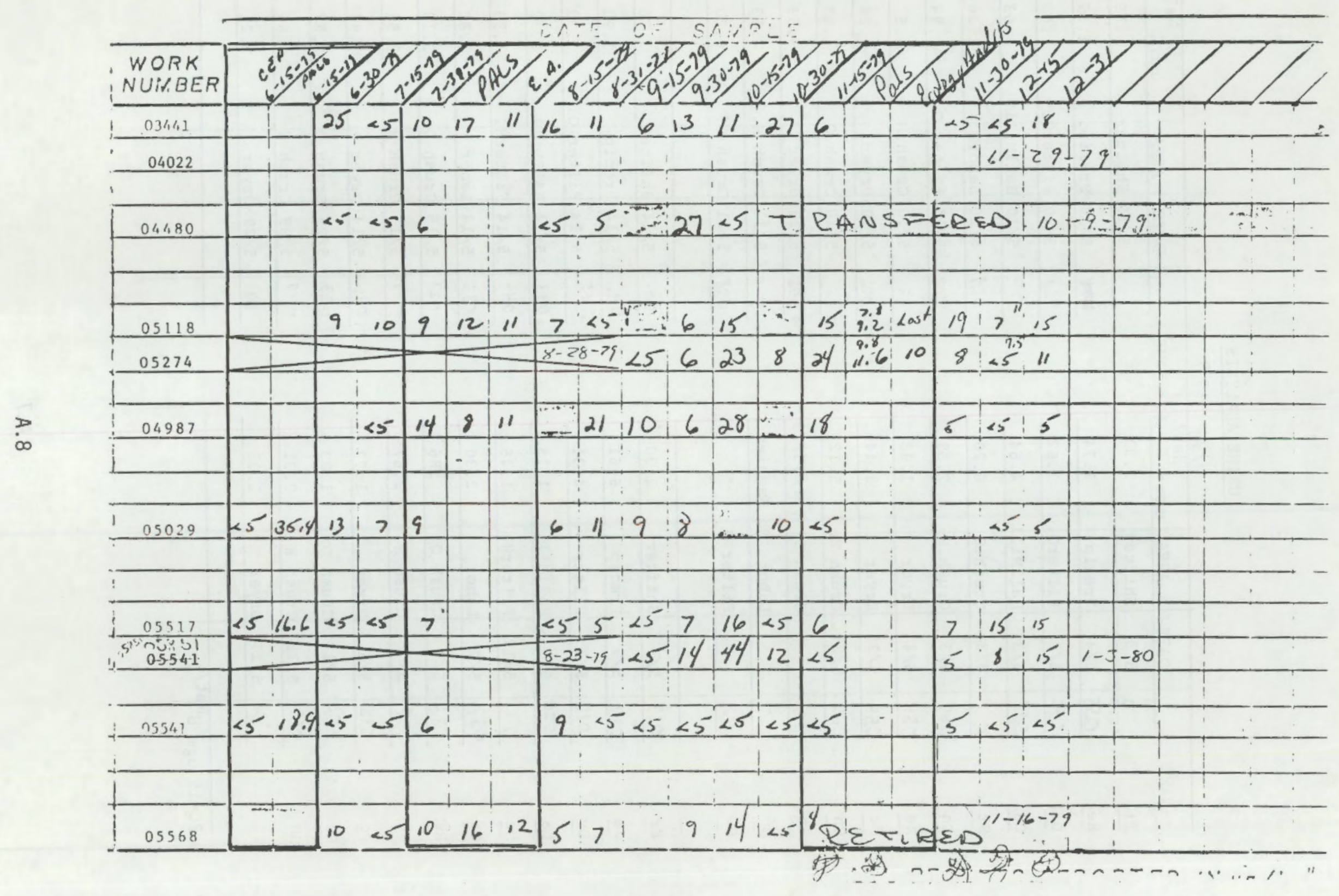




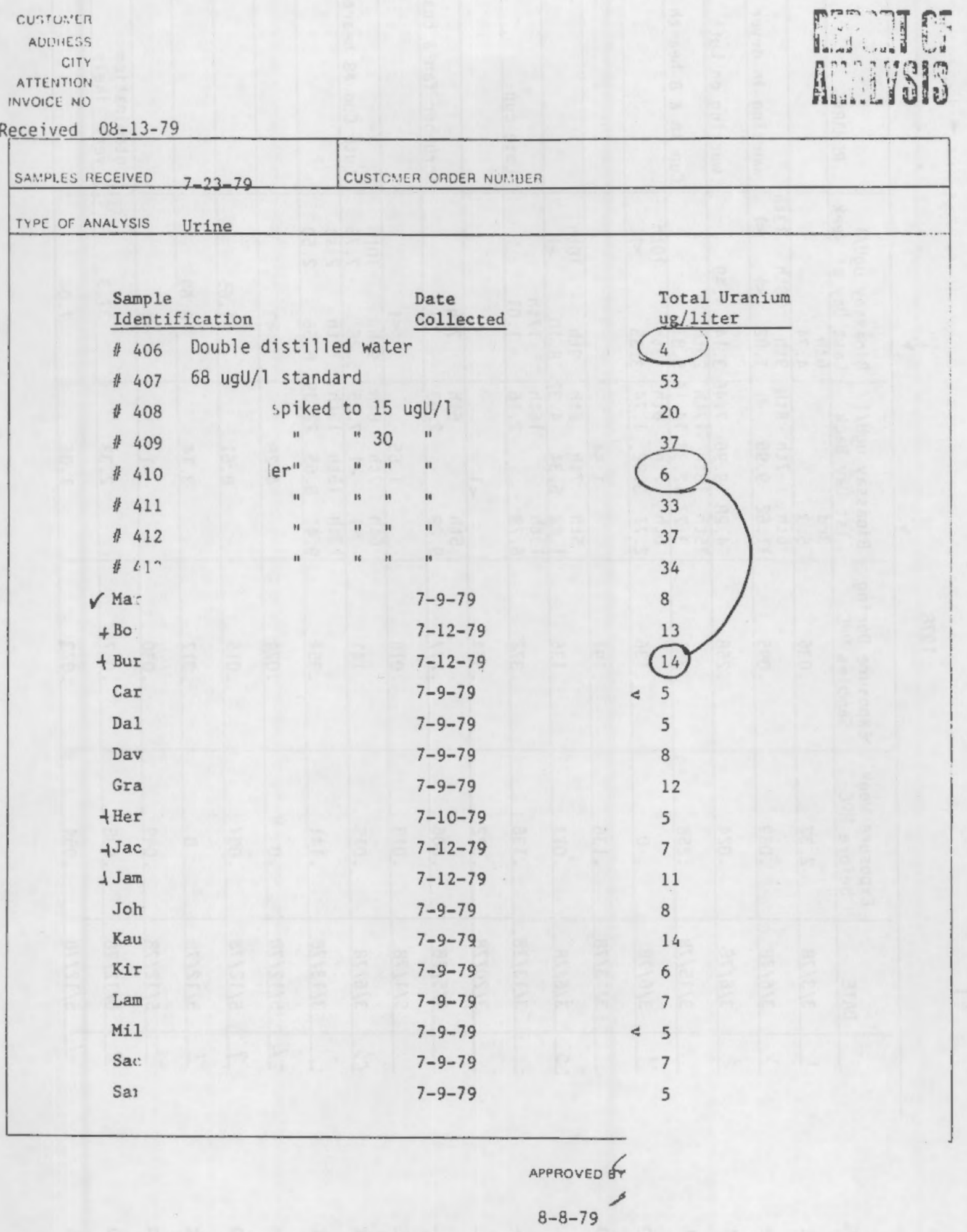


11

1978

$\therefore \quad \therefore \cdots+12$

- NAME

Bar:

Bow

Col

Co!

Con

con

De

:

\begin{tabular}{|c|c|c|c|c|c|c|}
\hline & & & 1978 & $\forall$ & $\therefore$ & \\
\hline & DATE & $\begin{array}{l}\text { Exposure Week } \\
\text { before MPC }\end{array}$ & $\begin{array}{c}\text { Exposure During } \\
\text { Samples MPC }\end{array}$ & $\begin{array}{l}\text { Bioassay ugu/l } \\
\text { 1st_Day_Back } \\
\text { 3rd }\end{array}$ & $\begin{array}{l}\text { Bioassay ugU/1 } \\
\text { Last Day of Week }\end{array}$ & REMMRKS \\
\hline 1 & $3 / 3 / 78$ & 2.32 & $\ldots .036$ & \begin{tabular}{|l|} 
3rd \\
5.3 \\
\end{tabular} & $\begin{array}{l}6.6 h \\
4.74 \\
\end{array}$ & \\
\hline$\therefore$ & $3 / 6 / 78$ & .039 & .095 & $\begin{array}{|ccc|}6 \text { th } & 7 \text { th } & 8 \text { th } \\
11.62 & 9.96 & <1 \\
\end{array}$ & $\begin{array}{lll}9 \text { th } & 10 \text { th } & 13 \text { th } \\
1.82 & <1 & <1\end{array}$ & working in dryer \\
\hline \multirow[t]{2}{*}{3} & $3 / 6 / 78$ & .024 & .258 & $\begin{array}{lll}4.28 & 9.96 & 7.46 \\
15 t h & 16 t h & 17+5\end{array}$ & $\frac{3.14 \quad 4.49}{20+h}$ & working on Lute \\
\hline & $3 / 15 / 78$ & .258 & .361 & $\mid \begin{array}{ccc}3.77 & 12.34 & 14.16 \\
6 \text { th } & 7 \text { th } & 8 \text { th }\end{array}$ & $\begin{array}{r}5.81 \\
9 t h\end{array}$ & Cup in $\# 8$ hearth \\
\hline \multirow[t]{2}{*}{ ! } & $3 / 6 / 78$ & 0 & .136 & $\begin{array}{rrr}6 \text { th } & 7 \text { th } & 8 \text { th } \\
2.71 & 3.82 & 1.74 \\
\end{array}$ & $\begin{array}{r}9 \text { th } \\
3.35 \\
\end{array}$ & \\
\hline & $i 3 / 13 / 78$ & .136 & .191 & 1.54 & & \\
\hline \multirow{5}{*}{25} & $3 / 6 / 78$ & .017 & .136 & $\begin{array}{|rrr|}6 \text { th } & 7 \text { th } & 8 \text { th } \\
7.82 & 5.34 & 4.37 \\
\end{array}$ & $\begin{array}{ll}9 \text { th } & \text { 10th } \\
8.10 & <1\end{array}$ & \\
\hline & $3 / 13 / 78$ & .136 & .372 & 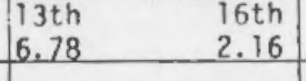 & $\begin{array}{l}17 \text { th } \\
1.01 \\
\end{array}$ & Lute cup \\
\hline & $3 / 20 / 78$ & .372 & .564 & $<1$ & & \\
\hline & $4 / 5 / 78$ & .006 & .277 & $\begin{array}{|rr|}5 \text { th } & 6 \text { th } \\
9.29 & 2.63 \\
\end{array}$ & $\begin{array}{r}7 \text { th } \\
<1\end{array}$ & Scrubber fan \& bearin \\
\hline & $5 / 1 / 78$ & .013 & .018 & 1.65 & $<1$ & \\
\hline de & $3 / 6 / 78$ & .015 & .141 & $\begin{array}{|rrr|}6 \text { th } & 7 \text { th } & 8 \text { th } \\
<1 & <1 & 7.25 \\
\end{array}$ & \begin{tabular}{|rr}
9 th & 10 th \\
5.26 & 7.76 \\
\end{tabular} & Lute Cup \#8 hearth \\
\hline - & $3 / 13 / 78$ & .141 & .354 & $\begin{array}{|lll|}13 \text { th } & 15 \text { th } & 16 \text { th } \\
9.41 & 8.65 & 22.39 \\
\end{array}$ & \begin{tabular}{|l|}
17 th \\
8.56 \\
\end{tabular} & \\
\hline-2 & $5 / 12 / 78$ & $.0 \mathrm{~V}$ & .024 & 4.28 & $\leq 1$ & \\
\hline 1 & $5 / 12 / 78$ & .007 & .015 & 8.61 & 1.65 & \\
\hline I & $5 / 12 / 78$ & 0 & .017 & 3.14 & 8.69 & \\
\hline$\because 3$ & $5 / 12 / 78$ & .049 & .030 & $<1$ & $\leq 1$ & \\
\hline$c$ & $-5 / 12 / 78$ & -.038 & .057 & 2.33 & 37.3 & $\begin{array}{r}\text { Contamination } \\
\text { very likely }\end{array}$ \\
\hline 11 & $5 / 12 / 78$ & .054 & .023 & 1.06 & 7.04 & \\
\hline
\end{tabular}




\begin{tabular}{|c|c|c|c|c|c|c|c|c|c|c|}
\hline & & & & & $\triangle T B C=$ & 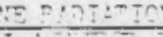 & & & & $n=1$ \\
\hline ब्र & & & CeIcuIn:ed & & $10=215$ & $2+6-5$ & $8-8=1=$ & $\therefore-2+5$ & $=+5=-1 . \mathrm{S}$ & \\
\hline Poo: & $\begin{array}{l}\text { Fos. } \\
\text { aniol }\end{array}$ & $=n+\cdots$ & 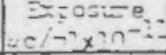 & $\therefore \quad \cdots=0$ & $\because a+n$ & CQLCULATED & 1 $\cdots=0$ & $\therefore a r=g$ & A & 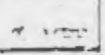 \\
\hline 011949 & 13,4 & 540 & 210.3045 & 52.574 & & & & & & \\
\hline & $2,3,4,5$ & 40 & 341.9393 & $55,48 s$ & & & & & & \\
\hline & & 2 & & & & & & & & \\
\hline 12110 & 2.35 & 32 & 14.5861 & 3.645 & & & & & & \\
\hline & & & & & & & & & & \\
\hline $12 / 17$ & 345 & 40 & 17.3375 & 4. 333 & & & & & & \\
\hline $2 / 24$ & 345 & 40 & 15.3784 & 3.843 & & & & & & \\
\hline 12131 & 134 & $=48$ & 16.9396 & 4.233 & & & 1975 & 2030 & 8993.8398 & 28.41 \\
\hline $11 / 7$ & 234 & 39 & 4.2322 & 1,057 & & & 20 & $2 4 \longdiv { 3 9 }$ & 8562.4254 & 23,478 \\
\hline & $7 !$ & & & & & & & & & \\
\hline $1 / 14$ & $3,4,5$ & 48 & 5.6779 & 7.418 & & & & & & \\
\hline $1 / 21$ & 2,45 & 540 & 5.7163 & 1.423 & & & & & & \\
\hline 28 & $5,5,5$ & 48 & 5,6779 & $1.4 / 8$ & & & & & & \\
\hline & $2>45$ & 540 & 18.6272 & 4.655 & & & & & & \\
\hline & 177 & & & & & & & & & \\
\hline $2 \sqrt{11}$ & $2,39,5$ & 540 & 11.4847 & 2870 & & & & & & \\
\hline $2 / 18$ & 3,45 & $4 a$ & 12,6044 & 4.650 & & & & & & \\
\hline $2 / 25$ & 34,5 & 48 & 19,3813 & $4.8 \mathrm{~m}$ & & & & & & \\
\hline 14 & $5,4,5$ & 40 & 7.0350 & 1.757 & & & & & & \\
\hline & 77 & & & & & & & & & \\
\hline $3 / 11$ & 345 & 40 & 2.0350 & 1.757 & & & & & & \\
\hline $3^{\prime} / 18$ & 2345 & $=40$ & 20899 & 1.770 & & & & & & \\
\hline 25 & 3,5 & 78 & 7.5654 & 1.890 & & & & & & \\
\hline 4 & $3,4,5$ & 40 & 5,6302 & 1.406 & & & & & & \\
\hline & 17 & & & & & & & & & \\
\hline 8 & $35-$ & 40 & 5.5551 & 1,358 & & & & & & \\
\hline 5 & $4^{\prime}, 5$ & 32 & 3.7939 & 0.947 & & & & & & \\
\hline 2/:22 & $3,4,5$ & 48 & 6.2327 & 1.557 & & & & & & \\
\hline 29 & 45 & 40 & 5.3432 & 1.335 & & & & & & \\
\hline & 7 & & & & & & & & & \\
\hline 5 & 245 & 40 & 5,2949 & 1.322 & & & & & & \\
\hline 113 & 345 & 40 & 5,1479 & 1.285 & & & & & & \\
\hline 120 & $3,4,5$ & 48 & 5.6552 & 1.412 & & & & & & \\
\hline 27 & $3,2,5$ & 44 & $3,95: 2$ & 0.908 & & & & & & \\
\hline & 17 & & & & & & & & & \\
\hline $6 / 3$ & 2,35 & 37 & 2,1643 & 6,539 & & & & & & \\
\hline 10 & 35 & 40 & 3,4229 & 0.855 & & & & & & \\
\hline 7 & 3,45 & 78 & 4.1906 & 1.046 & & & & & & \\
\hline 24 & 3,45 & 10 & 32.2983 & 8.073 & & & & & & \\
\hline & 17 & & & & & & & & & \\
\hline 211 & 395 & $4 /$ & 18. 0523 & 4.512 & & & & & & \\
\hline $7 / 8$ & 3,45 & 40 & 31.6960 & 7,923 & & & & & & \\
\hline $7 / 15$ & $3,3,43$ & 548 & 47,6054 & 11.899 & & & & & & \\
\hline $7<22$ & 2324 & 5.31 & 5.5779 & 1,393 & & & & & & \\
\hline & 77 & & & & & & & & & \\
\hline $2 / 29$ & $3,4,5$ & 40 & 5.6482 & 1.409 & & & & & & \\
\hline $8 / 5$ & 6364 & 32 & 5.2071 & 1.299 & & & & & & \\
\hline $8 / 12$ & 7,5 & $4 / 0$ & 5.2003 & 1424 & & & & & & \\
\hline $8 \% 19$ & 34s & 32 & 3.9010 & 0.924 & & & & & & \\
\hline 7 & 71 & & & & & & & & & \\
\hline $8 / 28$ & 24,5 & 16 & 1.9935 & 0.497 & & & & & & \\
\hline $3<2$ & 346 & 40 & 4.2299 & 1.056 & & & & & & \\
\hline $91 / 9$ & 2345 & 548 & 4 ein 145 & 1.152 & & & & & & \\
\hline $9<16$ & 3,45 & 475 & 4,1492 & 1.0 .36 & & & & & & \\
\hline 78 & 77 & & & & & & & & & \\
\hline $9 / 23$ & 345 & 32 & 2.6297 & 0.656 & & & & & & \\
\hline $9 / 30$ & 385 & 40 & 4.5426 & $\angle 134$ & & & & & & \\
\hline$|c\rangle / 6$ & rast & 48 & $3, \overline{8} 463$ & $2.5(20)$ & & & & & & \\
\hline & & & & & & & & & & \\
\hline & & & & & & & & & & \\
\hline & & & & & & & & & & \\
\hline & & & & & & & & & & \\
\hline & & & & & & & & & & \\
\hline & & & & & & & & & & \\
\hline & & & & & & & & & & \\
\hline & & & & & & & & & & \\
\hline & & & & & & & & & & \\
\hline & & & & & & & & & & \\
\hline & & & & & & & & & & \\
\hline & & & & & & & & & & \\
\hline & & & & & & & & & & \\
\hline
\end{tabular}



APPENDIX B

RECOMMENDATIONS FOR BIOASSAY PERFORMANCE CRITERIA AND AN AUDIT PROGRAM TO TEST THE LABORATORY 
APPENDIX B

\begin{abstract}
RECOMMENDATIONS FOR BIOASSAY PERFORMANCE CRITERIA AND AN AUDIT PROGRAM TO TEST THE LABORATORY
\end{abstract}

Analysis of uranium in urine is a common radiochemical procedure in which uranium is removed from the sample matrix and quantitatively measured. Evaluation of bioassay results can determine whether a worker may have incurred internal uranium exposure at the mill, estimate the rate of elimination of uranium from the body in urine at various times after intake, and determine the amount of uranium remaining in the body. Although natural uranium is toxic, it is not believed hazardous until the intake exceeds $2.7 \mathrm{mg}$ (ICRP 1968). Bioassay measurements must, therefore, be highly reliable so that the health physicist can take precautions whenever a worker is found to excrete uranium at or near hazardous levels.

The reliability of the bioassay analysis can be assured if performance criteria include a priori requirements for accuracy (bias) precision, and confidence. These performance criteria are established depending upon how well you need to identify the intake of uranium and control the potential for further exposure. For example, an internal dosimetry bioassay program could be established with performance criteria such that the probability is greater than $95 \%$ that all internal depositions exceeding $1 \%$ of the maximum permissible limits on dose will be identified from a routine bioassay sample.

Performance criteria for a uranium mill bioassay program should require a high deyree of confidence (e.g., $P>95 \%$ ) that all bioassay results greater than $5 \mu \mathrm{g}$ of $\mathrm{U} / \ell$ are detected. Three major performance criteria that should be considered are:

- Type I (a) and Type II (b) errors must not exceed 0.05 at the detection 1 imit. That is, no more than $5 \%$ of the samples should be juayea co contain no activity when, in ract, tne crue activity was $L_{d}$ or greater (Type II error). Additionally, no more than $5 \%$ of the samples containing no activity should be judged as containing activity (Type I error).

- Results should be unbiased.

- All results including negative values and those below the $L_{d}$ should be reported (i.e., no data censoring).

Two special levels that should be considered when establishing lower limits for the bioassay measurement are:

- The "decision limit" $\left(L_{C}\right)$ is the activity level at which a decision is made as to whether or not the sample contains activity. That is, if the reported activity of a sample is below $L_{c}$, the sample is 
judged to contain no activity and if the reported activity of a sample is at or above $L_{C}$, the sample is judged to contain activity.

- The "detection limit" $\left(L_{d}\right)$ is defined in relationship to $L_{c}$ such that the smallest true signal will be detected $95 \%$ of the time, i.e., a measurement result equal to $L_{d}$ may be relied upon $(95 \%$ of the time) to lead to detection. This is what is usually considered the detection limit at the $95 \%$ confidence level.

Once bioassay performance criteria for accuracy (bias), precision, and confidence are established, the health physicist should be responsible for auditing or testing the bioassay laboratory or vendor to ensure that the performance criteria are met. An audit program consists of submitting blank and spiked samples to the laboratory with the same characteristics as the actual samples collected in the routine bioassay program. Audit samples should be subinitted to the laboratory in a manner such that they cannot be differentiated from typical routine samples. In other words, audit samples should be submitted as blind and open tests in an amount up to approximately $10 \%$ to $15 \%$ of the total number of routine samples.

To test laboratory performance at the decision limit $\left(L_{c}\right)$, enough blank samples must be submitted so that the standard deviation $\left.\left(\mathrm{S}_{0}\right)\right)$ of the net activity can be determined when the sample contains no activity. If the distribution of the blank urine results are assumed Gaussian, then:

$$
L_{c}=\bar{x}_{0}+k_{\alpha} S_{0}
$$

where

$$
\begin{aligned}
x_{0}= & \sum_{i}\left(x_{i} / n\right) \\
S_{0}= & \sum_{i}\left(x_{i}-\bar{x}\right)^{2} /(n-1) \\
n= & \text { number of available audit samples } \\
K_{\alpha}= & \text { the upper percentile from the standard Gaussian distribution } \\
& \text { corresponding to the size of the desired Type I error (e.g., if } \alpha=0.05, \\
& \text { the } \left.K_{\alpha}=1.645\right)
\end{aligned}
$$

and

$$
L_{d}=L_{c}+K_{\beta} S_{d}
$$


where

$$
\begin{aligned}
& K_{\beta}= \text { the upper percentile from the standard Gaussian distribution } \\
& \text { corresponding to the size of the desired Type II (e.g., if } \\
&\left.\beta=0.05 \text {, the } K_{\beta}=1.645\right) \\
& S_{d}= \text { standard deviation of the net activity determined from measurements } \\
& \text { of spiked samples. }
\end{aligned}
$$

The health physicist should maintain a running table and chart of the data, $\bar{x}_{0}$, $S_{0}$, and $L_{C}$. The chart, along with the table, is convenient so that any trends with time can be easily observed. Table B.1 illustrates some of the relevant parameters for a few blank urine samples subinitted for uranium analysis. The table contains columns for date, audit results, $\bar{x}_{0}, S_{\rho}, L_{c}$ and the results from any outlier test. The table also indicates what results were deleted because they were outliers and what results were subsequently reinstated when future data indicated that a deleted result probably was not an outlier.

Whenever a new set of results are obtained, the table is updated. Before a new $\bar{X}_{0}, S_{0}$, and $L_{C}$ are calculated, the data needs to be inspected for outliers. This can be done by first visually inspecting the chart or table and then testing any suspicious data. After any outliers have been removed from

\begin{tabular}{|c|c|c|c|c|c|}
\hline Date & $\begin{array}{c}\text { Audit Results, } \\
\mu \mathrm{g} \text { of } U\end{array}$ & $\underline{x}_{e}$ & $s_{0}$ & $L_{c}$ & Outlier Test \\
\hline \multirow[t]{5}{*}{1} & 0.23 & & & & \\
\hline & 0.03 & & & & \\
\hline & 0.00 & & & & \\
\hline & 0.19 & & & & \\
\hline & 0.21 & 0.13 & 0.11 & 0.31 & \\
\hline 2 & 0.03 & & & & \\
\hline & 0.035 & & & & \\
\hline 3 & $0.85(a)$ & significant & outlier & $(<0.01)$ & $R_{11}=0.756$ \\
\hline
\end{tabular}
the data, the new $\bar{X}_{0}, S_{0}$, and $L_{c}$ are determined. Test sample results determined to be outliers are considered failures when laboratory performance is being evaluated.

TABLE B.1. Bioassay Data for Natural Uranium Blank Audit Samples

(a) This audit result has been determined to be an outlier according to the Dixon Criterion (Natrella 1966). Calculation of $L_{C}$ should not include outliers. 

NUREG/CR-2955

PNL -4550

$\mathrm{RH}$

\section{DISTRIBUTION}

No. of

Copies

\section{$\underline{\text { OFFSITE }}$}

Bud Reaveau

Energy Fuels Nuclear

P.0. Box 787

Blandings, UT 84511

Roy Cellan

Utah International

Lucky McMill

Shirley Basin, WY 82615

P. Donahoe

Environ. Improvement Div.

State of New Mexico

P.0. Box 968

Santa Fe, NM 87503

Richard Farrell

Homestake UNC

Partner

Grants, NM 87020

R. W. Helm, Mill Supv.

Western Nuc. Inc.

Field office

Jeffrey City, WY 82310

Arnold Acosta

Sweetwater Uranium Proj.

Minerals Exploration Co.

P.0. Box 1500

Rawlins, WY 83201

G. Beach

Div. of Health and Med. Svce.

New State Office Bldg.

Cheyenne, WY 82001

Paul Blair

Split Rock Mill

Western Nuclear Inc.

Jeffrey City, CO 82310
No. of

Copies

Jim Rucker

Minerals Exploration

P.0. Box 1500

Rawlins, WY 82301

J. L. Cleveland

Kerr-McGee Nuclear Corp.

Grants, NM 87020

Glenn Dooly

Pathfinder Mines Corp.

P.0. Box 831

Riverton, WY 82501

Bill Gray

Anaconda Corp.

P.0. Box 638

Grants, NM 87020

R. Adrian

Atlas Minerals

P.0. Box 1207

Moab, UT 84532

SJB Baker

$\mathrm{C} / 0$ Wester Nuclear Inc

134 Union Blvd., Suite 640

Lakewood, CO 80228

R. C. Beverly

Union Carbide Corp.

P.0. Box 1049

Grand Junction, C0 81501

Gray Bodgen, Director

Environ. \& Industrial Safety

Western Nuclear Inc.

134 Union Blvd., Suite 640

Lakewood, C0 80228

R. E. Bohm

Gulf Mineral Resources Co.

1720 S. Bellaire Street

Denver, CD 80222 
No. of

Copies

John Burnett

Rio Algom

P.0. Box 610

Moab, UT 84532

E. E. Kennedy

United Nuclear-Homestake Part.

P.0. Box 98

Grants, NM 87020

M. D. Lawton, Mill Mgr.

Rio Algom

P.0. Box 610

Moab, UT 84532

E. L. Nugent, Mine Mgr.

Pathfinder Mines Corp.

Riverton Mine \& Mill

P.0. Box 831

Riverton, WY 82501

Jim Massey, Mill Supv.

Union Carbide Corp.

Grand Junction office

Gas Hills, WY 82501

Ralph Peak, Mill Supt.

Pathfider Mines Corp.

Shirley Basin Mine

Shirley Basin, WY 82615

Robert $W$. Poyser

Pathfinder Mines Corp.

Lucky McMine

P.0. Box 831

Riverton, WY 82501

Tom Reynolds

Rio Algom

P.0. Box 610

Moab, UT 84532

T. E. Buhl

New Mexico Env. Improvement Div. P.0. Box 968

Santa Fe, NM 87503
No of

Copies

F. Jackson

Federal American Partners

Gas Hills Star Route

Riverton, WY 82501

T. J. Laverty, Mill Supv. Highlands Uranium Operations

Exxon Minerals Co., USA

P.0. Box 3020

Casper, WY 82602

Bob Lynn

Anaconda

Grants, NM 87020

D. Markley

Energy Fuels Nuclear

1515 Arapahoe

Denver, CO 80202

Karen McDowell

Petrotomics Co.

P.0. Box 2509

Shirley Basin, WY 82615

S. J. Pfaff

Petrotomics Co.

P.0. Box 2509

Shirley Basin, Wy 82615

David M. Range

Exxon Minerals Co.

P.0. Box 3020

Casper, WY 82602

J. D. Ritts

Sohio Natural Resources

P.0. Box 15201

Albuquerque, NM 87125

J. E. Russell

Utah International

Lucky Mc. Uranium Corp.

Shirley Basin, WY 82615 
No. of

Copies

Gerald L. Schierman

Union Carbide

P.0. Box 94

Uravan, CO 81436

Larry Snyder

Minerals Exploration

P.0. Box 1500

Rawlins, WY 82301

J. H. Whitman

Petrotonics Co.

P.0. Box 2509

Shirley Basin, WY 82615

Gordon Swanby

Atlas Minerals

2508 Prudential Plaza

1050 12th St

Denver, CO 80625

Don Lusher

Wyoming Minerals

Buffalo, WY 82834

George Meenoch

Western Nuclear Inc.

Sherwood Project

P.0. Box 392

Wellpinit, WA 99040

Gerald Sinke

Kerr-McGee Nuclear Corp.

Oklahoma City, OK 73125

Dr. Ted Wolff

Radiation Protection Section

Environment Improvement Div.

P.0. Box 968

Santa Fe, NM 87503

E. Scott

Bear Creek Uranium Co.

P.0. Box 2654

Casper, WY 82602
No. of

Copies

James B. Shannon

Highlands Uranium Operations

Exxon Minerals Co. USA

Casper, WY 82602

Jack Thompson

Dawn Mining $\mathrm{Co}$.

P.0. Box 25

Ford, WA 99013

George Worman

Pathfinder Mines Corp.

Shirley Basin Mine

Shirley Basin, WY 82615

Gary Chase

Bear Creek Uranium Co.

P.0. Box 2654

Casper, WY 82602

Mr. Kenneth Wright

Federal American Partners

Gas Hills Star Route

Riverton, WY 82501

Dr. David Shearer

Texas Department of Health

Bureau of Radiation Control

1100 W. 49th St.

Austin, TX 78756

Tom Wong

Union Carbide Corporation

P.0. Box 5100

Riverton, WY 82501

Dr. Noel Savignac

United Nuclear Corp. 4801 Indian School Road

P.0. Box 3951

Albuquerque, NM 87110

10 Marion Loomis

Wyoming Mining Assn.

Hitch Post Inn

P.0. Box 866

Cheyenne, WY 82001 
No. of

Copies

\section{Dennis Fike \\ Pathfinders Mines Corp. \\ Lucky McMine \\ P.0. Box 831 \\ Riverton, WY 82501 \\ Gerald Stewart}

Environmental Improve. Div.

State of New Mexico

P.0. Box 968

Sante Fe, NM 87503

Jim Bazemore

Sohio Natural Resources

P.0. Box 25201

Albuquerque, NM 87110

Bob Nelson

Dawn Mining Co.

P.0. Box 25

Ford, WA 99013

Mike Henderson

4420 S. David

Casper, WY 82601

Merrill Eisenbud

New York University Medical Center

Institute for Environmental Medicine

Tuxedo, NY 10987

David Hickman

New York University Medical Center

Institute for Environmental

Medicine

Tuxedo, NY 10987

Charles Friedman

Monsanto Research Corporation

Mound Laboratory

Miamisburg, $\mathrm{OH} 45342$
No. of

Copies

Frank Eidson

Inhalation Toxicology Research Institute

Lovelace Biomedical \& Environmental Research Institute

P.0. Box 5890

Albuquerque, NM 87185

Norman Cohen

New York University Medical Center

Institute for Environmental Medicine

Tuxedo, NY 10987

Bob Robinson

Monsanto Research Corporation

Mound Laboratory

Miamisburg, OH 45342

Clifford Rudy

Monsanto Research Corporation

Mound Laboratory

Miamisburg, $\mathrm{OH} 45342$

M. E. Wrenn

Radiobiology Laboratory

University of Utah

College of Medicine

B1dg. 522

Salt Lake City, UT 84112

Ken Skrable

University of Lowell

1 University Avenue

Lowell, MA D1854

U.S. Nuclear Regulatory Commission

Division of Technical Information and Document Control

7920 Norfolk Avenue

Bethesda, MD 20014 
No. of

Copies

10 NRC Technical Monitor

Dr. Judith Foulke

Office of Nuclear Regulatory Research

Health Effects Branch

Mailstop 1130 Silver Springs

Washington, DC 20555

Bob Alexander

Occupational Protect. Branch Mailstop 5650 Nicholson Ln. Washington, DC 20555

\section{R. B. Neal}

Occupational Protect. Branch Mailstop 5650 Nicholson Ln.

Washington, DC 20555

- Nancy Dennis

Region 1

631 Park Avenue

King of Prussia, PA 19406

Shlomo Yaniff

Health Effects Branch

Mailstop 1130 Silver Springs

Washington, OC 20555

Allen Brodsky

Occupational Protect. Branch

Mailstop 5650 Nicholson Ln.

Washington, DC 20555
No. of

Copies

Steve McGuire

Occupational Protect. Branch

Mailstop 5650 Nicholson Ln.

Washington, DC 20555

Dennis Sollenberger

Mailstop 396 Silver Springs

Washington, DC 20555

Peter Garcia

Region 4

611 Ryan Plaza Drive

Suite 1000

Arlington, TX 76011

\section{ONSITE}

51 Pacific Northwest Laboratory

T. L. Aldridge

L. G. Faust

D. R. Fisher

R. L. Kathren

J. A. Mahaffey

M. A. Mckinney

A. R. 01 sen

J. M. Selby

J. C. Simpson

H. B. Spitz (35)

Technical Information (5)

Publishing Coordination vg (2) 



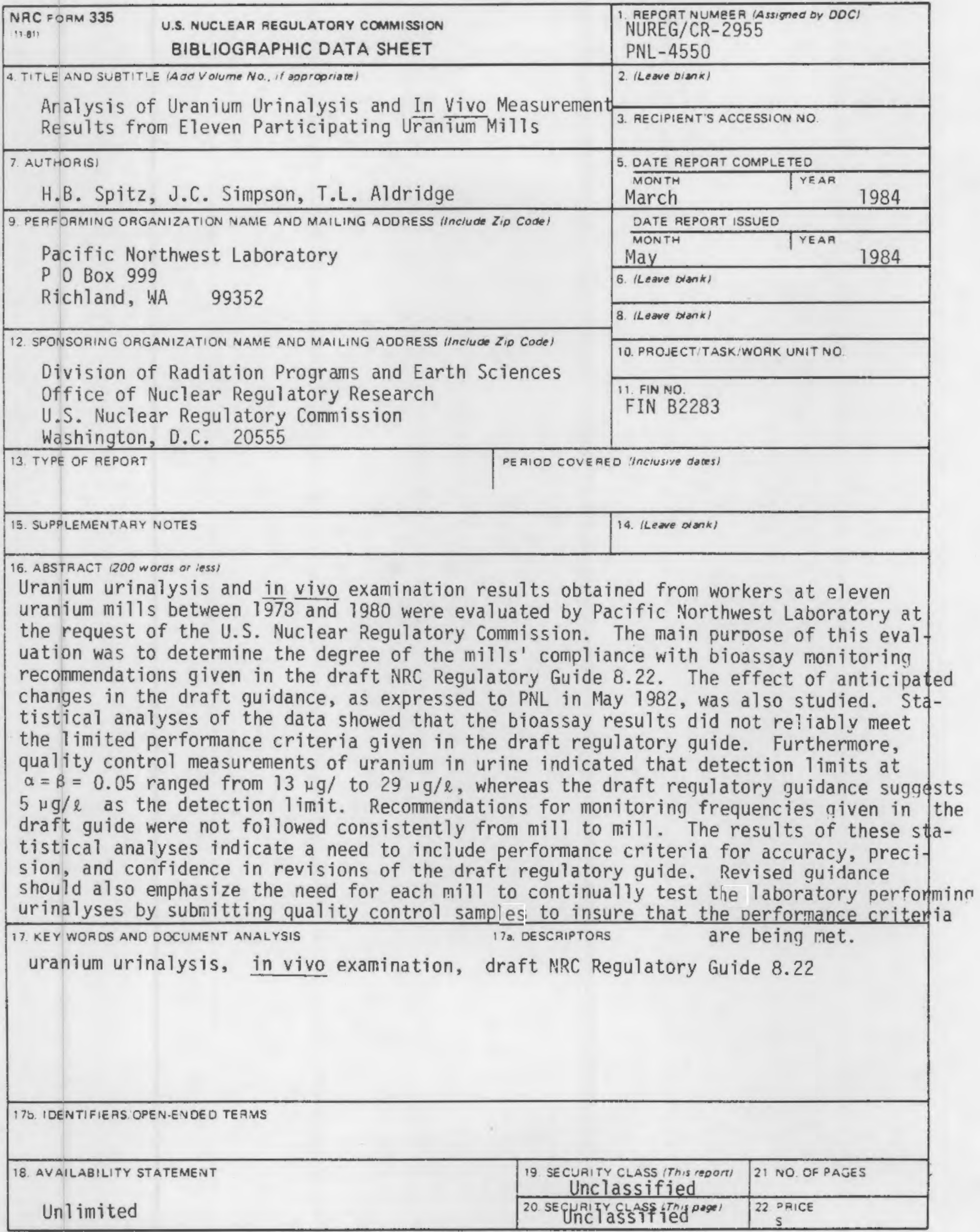


